\title{
Biological production in the Bellingshausen Sea from oxygen-to-argon ratios and oxygen triple isotopes
}

\author{
K. Castro-Morales ${ }^{1, *}$, N. Cassar ${ }^{2, * *}$, D. R. Shoosmith ${ }^{3}$, and J. Kaiser ${ }^{1}$ \\ ${ }^{1}$ School of Environmental Sciences, University of East Anglia, Norwich, UK \\ ${ }^{2}$ Geosciences Department, Princeton University, Princeton, USA \\ ${ }^{3}$ British Antarctic Survey, Cambridge, UK \\ * now at: Alfred Wegener Institute Helmholtz Centre for Polar and Marine Research, Bremerhaven, Germany \\ ** now at: Division of Earth and Ocean Sciences, Nicholas School of the Environment, Duke University, Durham, NC, USA \\ Correspondence to: K. Castro-Morales (karel.castro-morales@awi.de)
}

Received: 15 October 2012 - Published in Biogeosciences Discuss.: 15 November 2012

Revised: 27 February 2013 - Accepted: 14 March 2013 - Published: 5 April 2013

\begin{abstract}
We present estimates of mixed-layer net community oxygen production $(N)$ and gross oxygen production $(G)$ of the Bellingshausen Sea in March and April 2007. $N$ was derived from oxygen-to-argon $\left(\mathrm{O}_{2} / \mathrm{Ar}\right)$ ratios; $G$ was derived using the dual-delta method from triple oxygen isotope measurements. In addition, $\mathrm{O}_{2}$ profiles were collected at 253 CTD stations. $N$ is often approximated by the biological oxygen air-sea exchange flux $\left(F_{\text {bio }}\right)$ based on the $\mathrm{O}_{2} / \mathrm{Ar}$ supersaturation, assuming that significant horizontal or vertical fluxes are absent. Here we show that the effect of vertical fluxes alone can account for $F_{\text {bio }}$ values $<0$ in large parts of the Bellingshausen Sea towards the end of the productive season, which could otherwise be mistaken to represent net heterotrophy. Thus, improved estimates of mixed-layer $N$ can be derived from the sum of $F_{\text {bio }}, F_{\mathrm{e}}$ (entrainment from the upper thermocline during mixed-layer deepening) and $F_{\mathrm{v}}$ (diapycnal eddy diffusion across the base of the mixed layer). In the winter sea ice zone (WSIZ), the corresponding correction results in a small change of $F_{\text {bio }}=(30 \pm 17) \mathrm{mmol} \mathrm{m}^{-2} \mathrm{~d}^{-1}$ to $N=(34 \pm 17) \mathrm{mmol} \mathrm{m}^{-2} \mathrm{~d}^{-1}$. However, in the permanent open ocean zone (POOZ), the original $F_{\text {bio }}$ value of $(-17 \pm 10) \mathrm{mmol} \mathrm{m}^{-2} \mathrm{~d}^{-1}$ gives a corrected value for $N$ of $(-2 \pm 18) \mathrm{mmol} \mathrm{m}^{-2} \mathrm{~d}^{-1}$. We hypothesize that in the WSIZ, enhanced water column stability due to the release of freshwater and nutrients from sea ice melt may account for the higher $N$ value. These results stress the importance of accounting for physical biases when estimating mixed-layer marine productivity from in situ $\mathrm{O}_{2} / \mathrm{Ar}$ ratios.
\end{abstract}

\section{Introduction}

The Bellingshausen Sea is one of the less explored regions in Antarctica. It is located in the West Antarctic Peninsula (WAP) region and includes one of the major shelf areas in the Southern Ocean (SO), characterized by high phytoplankton biomass and high concentrations of chlorophyll $a$ and iron in surface waters (Holm-Hansen et al., 2005). Factors such as water column stability, irradiance and nutrient input are responsible for the high biomass and complex phytoplankton community in the region (Boyd et al., 1995; Garibotti et al., 2003; Smith and Comiso, 2008; Vernet et al., 2008).

During the last decade, the waters of the WAP have experienced a mean increase of $0.5^{\circ} \mathrm{C}$ in the top $100 \mathrm{~m}$ of the water column with the largest changes in winter (Holland et al., 2010; Meredith and King, 2005; Meredith et al., 2010; Montes-Hugo et al., 2010). Particularly, the Bellingshausen Sea has been affected by this rapid oceanic and atmospheric warming; both of which have had consequences on its ice shelves, such as Wilkins Ice Shelf (Graham et al., 2011). The invasion of relatively warm circumpolar deep water (CDW) onto the continental shelf is likely to be the main driver for ice shelf thinning and sea ice melting in the region (Jacobs et al., 1996; Jenkins and Jacobs, 2008). Furthermore, climate change in the SO may have led to increased wind speeds (Le Quéré et al., 2007) with implications for sea ice formation and persistence (Cook et al., 2005). A stronger mixing regime can affect the structure of the water column, nutrient supply by upwelling, as well as phytoplankton abundance 
and community composition (Arrigo et al., 2008). Warming can also drive deoxygenation, to which the Southern Ocean is particularly susceptible (Keeling and Garcia, 2002; Matear et al., 2000).

Because of the fast changes occurring in waters of the WAP, it is important to evaluate the current state of the marine communities in the region, particularly changes in marine productivity. Previous estimates of marine biological production in the Bellingshausen Sea were based on discrete measurements of ${ }^{14} \mathrm{C}$ assimilation, chlorophyll $a$ concentrations, seasonal inorganic nutrient deficits and phytoplankton abundance (i.e., Boyd et al., 1995; Garibotti et al., 2003; Serebrennikova and Fanning, 2004; Turner and Owens, 1995; Vernet et al., 2008). Marine production from remotely sensed ocean color in the Southern Ocean has been also performed (Arrigo et al., 2008).

Here we present estimates of mixed-layer average net community oxygen production $(N)$ and gross oxygen production $(G)$ in the Bellingshausen Sea during the period of February to April 2007, based on continuous ship measurements of $\mathrm{O}_{2} / \mathrm{Ar}$ ratios and discrete samples for oxygen triple isotopes.

The $\mathrm{O}_{2} / \mathrm{Ar}$ and oxygen triple isotope techniques have been applied before in the SO (Cassar et al., 2007, 2011; Guéguen and Tortell, 2008; Reuer et al., 2007; Tortell and Long, 2009), including the Bellingshausen Sea (Hendricks et al., 2004; Huang et al., 2012). $\mathrm{O}_{2} / \mathrm{Ar}$ only has been used in the Ross Sea (Tortell et al., 2011) and Amundsen Sea (Tortell et al., 2012). Hendricks' productivity estimates were based on discrete sampling away from the continental shelf, but did not resolve the direct influence of sea ice along the shelf. The study area of Huang et al. (2012) was located in the Palmer Long-Term Ecological Research (LTER) region, north of our area of study, and comprised a coarser grid of hydrographic stations than the present study, mainly outside the sea ice zone.

The $\mathrm{O}_{2} / \mathrm{Ar}$ approach is used to measure the biological oxygen air-sea exchange flux, $F_{\text {bio }}$. Neglecting the influence of vertical and horizontal transport on the mixed-layer $\mathrm{O}_{2}$ mass balance, $N$ is approximated by $F_{\text {bio }}$ (Kaiser et al., 2005). Previous studies in the Southern Ocean did not try to establish whether the observed negative $F_{\text {bio }}$ values were due to mixing with undersaturated waters or whether they reflected actual heterotrophy (Hendricks et al., 2005; Reuer et al., 2007).

Recent observations in other world's oceans have concluded that the consideration of physical effects, such as entrainment of subsurface waters into the mixed layer, in the productivity estimates using the $\mathrm{O}_{2}$ budget approach must be taken into account (i.e., Hamme and Emerson, 2006; Luz and Barkan, 2009; Nicholson et al., 2012). Mixing and entrainment processes at the base of the mixed layer can lead to underestimation of $N$ by the $\mathrm{O}_{2}$ budget by as much as $80 \%$ in the subtropical gyres (Nicholson et al., 2012). In the present study we explore the influence of entrainment of water from the upper thermocline during mixed-layer deepening and di- apycnal eddy diffusion across the base of the mixed layer on the mixed-layer $\mathrm{O}_{2}$ mass balance. The influence of horizontal transport is neglected because strong currents and fronts and associated gradients are absent in the interior of the Bellingshausen Sea, with the only prominent front centered at $67^{\circ} \mathrm{S}$ and $85^{\circ} \mathrm{W}$ off our study area (Pollard et al., 1995). Although the derivation of $G$ using the oxygen triple isotope technique may be affected by the same physical processes (Hendricks et al., 2005), here we only investigate their influence on $N$. We also investigate variations in $F_{\text {bio }}$ in relation to the marginal ice zone (MIZ) and the stability of the water column. Finally, we compare our results to previous productivity estimates in the region.

\section{Area of study}

The present study was carried out during 38 days (3 March to 9 April 2007) onboard RRS James Clark Ross within the framework of the British Antarctic Survey's ACES-FOCAS project (Antarctic Climate and the Earth System-Forcing from the Oceans, Clouds, Atmosphere and Sea-ice). The surveyed section in the Bellingshausen Sea lies between $66^{\circ}$ and $73^{\circ} \mathrm{S}$ and between $66^{\circ}$ and $93^{\circ} \mathrm{W}$. It is the southernmost limit of the WAP, with the latter extending to the northern tip of the peninsula and to the shelf break in the west (Ducklow et al., 2007). The sampling period coincided with the transition from summer to autumn, late melting winter ice and the formation of new ice.

The Bellingshausen Sea is located in the Antarctic Zone (AZ), in a transition region between the Antarctic continental shelf, the shelf break and the open ocean, often delimited by the $3000 \mathrm{~m}$ isobath (Fig. 1). Two zones can be distinguished within the AZ: the sea ice zone, which is predominantly seasonal with about $80 \%$ of the first-year ice that melts back each summer (Sturm and Masson, 2010); and the permanent open ocean zone (POOZ), where sea ice is absent year-round. In this work we will refer to the sea ice zone as the winter sea ice zone (WSIZ) hereinafter in order to refer specifically to a region that is ice covered in winter only and mostly free of ice during summer.

The MIZ separates the WSIZ and POOZ (Hiraike and Ikeda, 2009; Vernet et al., 2008). In the Bellingshausen Sea, the MIZ can normally be found between $65^{\circ} \mathrm{S}$ and $70^{\circ} \mathrm{S}$ and between $80^{\circ} \mathrm{W}$ and $87^{\circ} \mathrm{W}$ (Turner and Owens, 1995), about $100 \mathrm{~km}$ offshore during summer and $200 \mathrm{~km}$ offshore during winter.

The hydrography of the Bellingshausen Sea is influenced by bottom topography, coastlines and sea ice seasonality. The Antarctic Circumpolar Current (ACC), flowing around the Antarctic continent, supplies CDW to the shelf in this region. The formation and transport of surface water masses varies seasonally, and is dependent mainly on the freshwater input from melting ice and vertical mixing. 


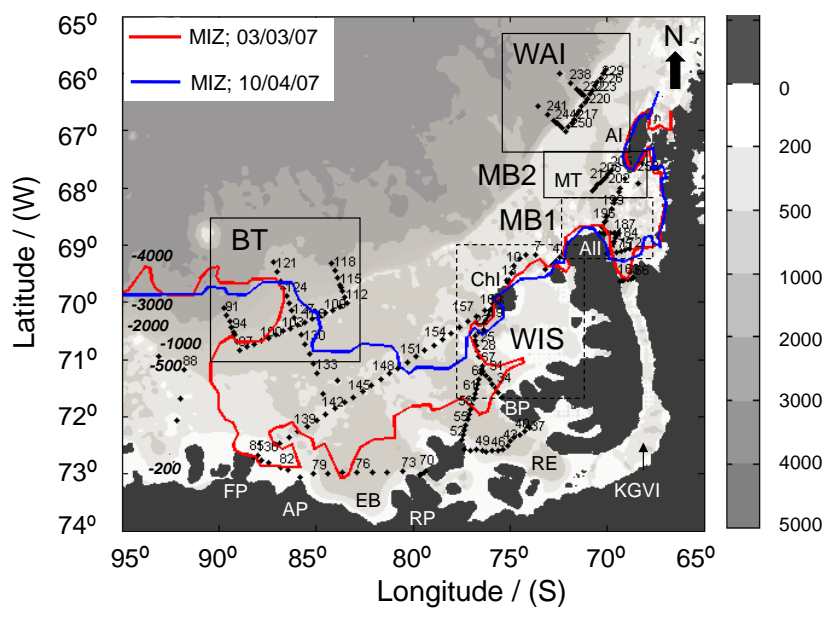

Fig. 1. Area of study for cruise JR165 in the Bellingshausen Sea during summer 2007. Black dots indicate the location of the CTD stations occupied during the cruise. The location of the marginal ice zone (MIZ) from AMSR-E satellite images is also shown at the beginning and end of the cruise. Main coastal features (from west to east): FP, Fletcher Peninsula; AP, Allison Peninsula; EB, Eltanin Bay; RP, Rydberg Peninsula; RE, Ronne Entrance; BP, Beethoven Peninsula; KGVI, King George VI Sound; ChI, Charcot Island; AlI, Alexander Island; MT, Marguerite Trough; AI, Adelaide Island. Stations in the WSIZ are outlined by dashed-line rectangles: WIS, Wilkins Ice Shelf and MB1, Marguerite Bay 1; stations in the permanent open ocean zone (POOZ) by solid line rectangles: BT, Belgica Trough; MB2, Marguerite Bay 2 and WAI, west of Adelaide Island.

The interaction between glacial water, sea ice melt water (MW) and oceanic waters in the Bellingshausen Sea affects the biological productivity distribution. In the Bellingshausen Sea, the main water masses are the following: CDW, entering the shelf as an extension of the ACC; AASW (Antarctic surface water), filling the upper $200 \mathrm{~m}$ during summer and autumn and extending from the Antarctic continent to the Antarctic Polar Front (APF); WW (winter water), formed during winter below the packed ice and dominating the deep mixed layer (i.e., > $100 \mathrm{~m}$ ) until early spring, when it is replaced by AASW; and MW released during summer from the coast and shelf areas covered with ice. Its release stabilizes the water column during the peak of the growing season (Serebrennikova and Fanning, 2004; Smith et al., 1999).

Through light availability and nutrient release, sea ice affects biological community composition and abundance (Garibotti et al., 2005a; Serebrennikova and Fanning, 2004; Vernet et al., 2008). During early spring, iron and algae are released from the melting sea ice (Hopkinson et al., 2007). This process, and the presence at the surface of nutrient-rich WW in a stratifying water column, is believed to lead to the spring phytoplankton blooms (Boyd et al., 2000; Martin et al., 1991) especially near the MIZ.
During the peak growing season in summer (January), chlorophyll $a$, carbon biomass and phytoplankton abundance are highly variable (Garibotti et al., 2005a; Smith et al., 2008; Vernet et al., 2008). At this stage, blooms persist for several weeks and diatom communities dominate the shelf waters of the Bellingshausen Sea (Garibotti et al., 2005a, 2003; Mura et al., 1995; Smith et al., 2008).

As the growing season evolves, silicate and nitrate become depleted. Iron concentration also decreases $(<0.1 \mathrm{nM})$, further limiting phytoplankton growth (Smith et al., 2000). By March, seasonal heating and mixing due to wind stress further erode the WW replaced by the AASW. This is especially the case in the POOZ.

From November to March (late spring to summer) MW dominates close to the coast. During these months, weaker winds and the stratified water column result in shallow summer mixed layers $(<50 \mathrm{~m})$ (Holm-Hansen et al., 2005). In the WSIZ, MW replaces WW in the mixed layer, but leaves a remnant of WW underneath (Garibotti et al., 2003; Vernet et al., 2008), storing the properties of the upper water column of the preceding winter. This has been observed previously in the WAP (Serebrennikova and Fanning, 2004) and in the MIZ of the Australian sector of the SO, where elevated nutrient content reflects remnant winter mixed layer (Ishii et al., 2002).

\section{Methods}

\subsection{Hydrographic stations and underway measurements}

Vertical profiles of temperature $(\theta)$, salinity $(S)$ and dissolved oxygen concentration $\left(c\left(\mathrm{O}_{2}\right)\right)$ were obtained at 253 CTD stations (Fig. 1). $S$ was measured with two conductivity sensors calibrated against discrete samples analyzed onboard with a Guildline Autosal 8400B. $\theta$ and $c\left(\mathrm{O}_{2}\right)$ were measured with high-precision digital reversing thermometers (Sea-Bird SBE35) and two $\mathrm{O}_{2}$ sensors (CTD-O ${ }_{2}$; Sea-Bird SBE43), respectively, mounted on the rosette. The $\mathrm{O}_{2}$ sensors responded less rapidly than the temperature and conductivity CTD sensors. Sensor lags for the two $\mathrm{O}_{2}$ sensors were $8 \mathrm{~s}$ and $9 \mathrm{~s}$, respectively, and were established by finding the lag time that minimized the root-mean-squared differences between downcast and upcast. One of the $\mathrm{O}_{2}$ sensors proved to be more stable and was selected for calibration. $\mathrm{O}_{2}$ profiles in deep casts $(>1000 \mathrm{~m})$ have been reported to be affected by pressure hysteresis (Sea-Bird Electronics, 2010). However, we observed little hysteresis on 38 of our CTD profiles which reached depths greater than $1000 \mathrm{~m}$. A correction had to be applied to the pressure sensor, which amounted to the following values: stations $0-21:-1.21 \mathrm{dbar} ; 22-85$ : -0.71 dbar; 86-164: -1.05 dbar; $165-253$ : -0.80 dbar. All measurements were vertically averaged in steps of $2 \mathrm{dbar}$. 
A total of 276 discrete seawater samples from the CTD profiles (and 186 from the continuous underway supply, see below) were collected for $\mathrm{O}_{2}$ sensor calibration and analyzed onboard using whole-bottle Winkler titration (Dickson, 1996) with photometric end-point detection. The calibration was made using the upcast CTD values at the density levels where the bottles were closed. We obtained a repeatability of $0.29 \mu \mathrm{mol} \mathrm{kg}{ }^{-1}$ for 76 duplicate samples. The average difference between non-calibrated CTD- $\mathrm{O}_{2}$ and Winkler data was $(+3.9 \pm 3.2) \mu \mathrm{mol} \mathrm{kg} \mathrm{kg}^{-1}$, and after calibration was $(+1.1 \pm 3.9) \mu \mathrm{mol} \mathrm{kg}^{-1}$.

Supporting physical variables were also measured using the underway seawater sampling system, which has an intake at a nominal depth of $6 \mathrm{~m}$ near the bow of the ship. Sea surface temperature $\left(\theta_{0}\right)$ was measured directly at the intake; sea surface salinity $\left(S_{0}\right)$ and $\mathrm{O}_{2}$ concentrations were recorded further downstream, using a Sea-Bird Electronics (SBE) thermosalinograph and an $\mathrm{O}_{2}$ optode (Model 3835, Aanderaa Instruments AS, Bergen, Norway), respectively. The delay from the sample intake to the measurement point for salinity and oxygen was $2 \mathrm{~min}$. This was corroborated by the change in temperature recorded in the optode from warm (above $10^{\circ} \mathrm{C}$ ) to close to seawater freezing point $\left(-1.8^{\circ} \mathrm{C}\right.$ ) in regions with ice surrounding. These events were clear during a transition of no underway water flow to flow restoration at a time recorded by the flowmeter located at the underway intake. The delay caused a warming of $(0.65 \pm 0.1)^{\circ} \mathrm{C}$. $S_{0}$ was calibrated using discrete samples analyzed onboard in the same way as for the CTD sensor. A constant offset of 0.0337 was added in order to correct the underway salinity record. The underway $\mathrm{O}_{2}$ measurements were calibrated against discrete samples collected from the underway system. The latter were analyzed onboard by Winkler titration, in the same way as for the CTD- $\mathrm{O}_{2}$ calibration. The oxygen concentration from the optode was calibrated following Kaiser et al. (2005). The average difference between Winkler data and noncalibrated underway $\mathrm{O}_{2}$ was $(-0.1 \pm 2.8) \mu \mathrm{mol} \mathrm{kg}{ }^{-1}$, and after optode calibration the difference was reduced to $(0.0 \pm 0.6) \mu \mathrm{mol} \mathrm{kg}{ }^{-1}$. From the meteorological station onboard, we obtained barometric pressure $(P)$ and wind speed. The latter was corrected to $10 \mathrm{~m}$ above sea level $\left(u_{10}\right)$ (Johnson, 1999).

To calculate the biological oxygen air-sea exchange flux and to estimate net community production, we continuously measured $\mathrm{O}_{2} / \mathrm{Ar}$ ratios in the underway sampling system by membrane inlet mass spectrometry (MIMS) (Kaiser et al., 2005; Kana et al., 1994; Tortell, 2005). Seawater from the ship's underway system was pumped through a chamber with a Teflon AF membrane (Random Technologies). The membrane was connected to the vacuum of a quadrupole mass spectrometer (Pfeiffer Vacuum Prisma). Temperature effects and water vapor pressure variations in the measurements were reduced by keeping the membrane in a water bath at a constant temperature of $0^{\circ} \mathrm{C} . \mathrm{O}_{2}(\mathrm{~m} / \mathrm{z} 32)$ to $\mathrm{Ar}(\mathrm{m} / \mathrm{z} 40)$ ion current ratio measurements were made every $6 \mathrm{~s}$ with a short-term $(2 \mathrm{~min})$ repeatability of $0.05 \%$. Our continuous high-frequency $\mathrm{O}_{2} / \mathrm{Ar}$ measurements allow us to identify marine productivity gradients and large variability at high spatial $(1 \mathrm{~km})$ and temporal $(3 \mathrm{~min})$ resolution.

For calibration of the $\mathrm{O}_{2} / \mathrm{Ar}$ measurements, discrete samples were drawn into evacuated bottles. After the cruise, liquid and gas phase had equilibrated. Most of the water was drained and water vapor, $\mathrm{N}_{2}$ and $\mathrm{CO}_{2}$ were removed using an extraction line comprising cryogenic and gas-chromatographic purification steps. The remaining $\mathrm{O}_{2}$ and Ar mixture was analyzed by isotope ratio mass spectrometry (IRMS) (Thermo Finnigan MAT 252) for ion beam intensities at $\mathrm{m} / \mathrm{z}, 32$ and 40 using peak jumping (Luz and Barkan, 2000). To derive gross photosynthetic $\mathrm{O}_{2}$ production from oxygen triple isotopes, the same samples were used to measure the relative ${ }^{17} \mathrm{O} /{ }^{16} \mathrm{O}$ and ${ }^{18} \mathrm{O} /{ }^{16} \mathrm{O}$ isotope ratio differences between dissolved $\mathrm{O}_{2}$ and air $\mathrm{O}_{2}\left({ }^{17} \delta\right.$ and $\left.{ }^{18} \delta\right)$.

\subsection{Sea-to-air $\mathrm{O}_{2}$ flux $\left(F_{\mathrm{g}}\right)$ calculation}

The supersaturation of $\mathrm{O}_{2}, \Delta\left(\mathrm{O}_{2}\right)$ is given by

$\Delta\left(\mathrm{O}_{2}\right)=\frac{c\left(\mathrm{O}_{2}\right)}{c_{\mathrm{eq}}\left(\mathrm{O}_{2}\right)}-1$,

where $c\left(\mathrm{O}_{2}\right)$ is the measured $\mathrm{O}_{2}$ concentration and $c_{\mathrm{eq}}\left(\mathrm{O}_{2}\right)$ is the $\mathrm{O}_{2}$ concentration at equilibrium with the atmosphere, calculated at in situ temperature, salinity and pressure (Garcia and Gordon, 1992, 1993). $\Delta\left(\mathrm{O}_{2}\right)$ can be negative, in which case it represents an oxygen undersaturation.

The flux of oxygen through the air-sea interface $\left(F_{\mathrm{g}}\right)$ is calculated from

$F_{\mathrm{g}}=k_{\mathrm{w}} c_{\mathrm{eq}}\left(\mathrm{O}_{2}\right) \Delta\left(\mathrm{O}_{2}\right)$,

where $k_{w}$ is the $\mathrm{O}_{2}$ gas exchange coefficient. Positive $F_{\mathrm{g}}$ values represent a net flux from the ocean to the atmosphere. $k_{w}$ was parameterized in terms of wind speed following Sweeney et al. (2007), averaged for 60 days prior to sampling using the method suggested by Reuer et al. (2007), and the mixed-layer depth defined by the vertical distribution of $\mathrm{O}_{2}$ following Castro-Morales and Kaiser (2012). Wind speeds were obtained from the European Centre for MediumRange Weather Forecasts (ECMWF, $6 \mathrm{~h}$ resolution, operational analysis, $1^{\circ} \times 1^{\circ}$ ) and varied during the cruise from 1 to $27 \mathrm{~m} \mathrm{~s}^{-1}$, with a mean of $8 \mathrm{~m} \mathrm{~s}^{-1}$. The root-mean-squared difference between ship winds $\left(u_{10}\right)$ and ECMWF winds was $2.5 \mathrm{~m} \mathrm{~s}^{-1}$. The absolute difference between the ECMWF wind product and $u_{10}$ was $(0.8 \pm 2.4) \mathrm{m} \mathrm{s}^{-1}$. Considering the mixed-layer depths and gas exchange coefficients, the residence time of $\mathrm{O}_{2}$ in the upper mixed layer was on average 25 days.

\subsection{Biological $\mathrm{O}_{2}$ flux $\left(\mathrm{F}_{\text {bio }}\right)$ determination from $\mathrm{O}_{2} / \mathrm{Ar}$ ratios}

The $\mathrm{O}_{2} / \mathrm{Ar}$ method to estimate net community production exploits the similar solubility characteristics of these two gases. 
Basically, it "corrects" the $\mathrm{O}_{2}$ supersaturation for physical effects due to temperature, salinity or pressure changes and bubble effects. The biological oxygen supersaturation, $\Delta\left(\mathrm{O}_{2} / \mathrm{Ar}\right)$, is defined as the relative deviation of the $\mathrm{O}_{2} / \mathrm{Ar}$ ratio in the sample to the $\mathrm{O}_{2} / \mathrm{Ar}$ ratio at equilibrium with the atmosphere (Craig and Hayward, 1987; Emerson et al., 1995; Kaiser et al., 2005; Spitzer and Jenkins, 1989),

$\Delta\left(\mathrm{O}_{2} / \mathrm{Ar}\right)=\frac{c\left(\mathrm{O}_{2}\right) / c(\mathrm{Ar})}{c_{\mathrm{eq}}\left(\mathrm{O}_{2}\right) / c_{\mathrm{eq}}(\mathrm{Ar})}-1$,

where $c_{\mathrm{eq}}\left(\mathrm{O}_{2}\right)$ and $c_{\mathrm{eq}}(\mathrm{Ar})$ are calculated as a function of temperature and salinity (Garcia and Gordon, 1992, 1993; Hamme and Emerson, 2004).

The biological oxygen air-sea exchange flux is defined as

$F_{\text {bio }}=k_{\mathrm{w}} c_{\mathrm{eq}}\left(\mathrm{O}_{2}\right) \Delta\left(\mathrm{O}_{2} / \mathrm{Ar}\right)$.

A positive $F_{\text {bio }}$ value corresponds to outgassing of biologically produced $\mathrm{O}_{2}$ from the mixed layer.

To estimate the standard error in our measurements, we measured aliquots of air-saturated water prepared and analyzed in the laboratory in the same way as the seawater samples. A total of 11 air-saturated water measurements gave a standard error in $\Delta\left(\mathrm{O}_{2} / \mathrm{Ar}\right)$ of $0.05 \%$, which does not contribute significantly to the overall uncertainty in $F_{\text {bio }}$. The uncertainty in $F_{\text {bio }}$ is mainly due to the wind-speed-dependent parameterization of the gas transfer coefficient $\left(k_{w}\right)$, which according to Sweeney et al. (2007) solely accounts for $15 \%$.

At steady state and in the absence of mixing, $F_{\text {bio }}$ is interpreted as biological net community production $N$ averaged over the residence time of water in the mixed layer, but this does not account for physical mixing process interpretation. We here quantify at least part of these processes by estimating the influence of entrainment of thermocline waters when the mixed layer deepens (Sect. 3.4) and vertical eddy diffusion as a result of the oxygen concentration gradient of oxygen across the base of the mixed layer (Sect. 3.5).

To calculate net community production in terms of carbon $(N(\mathrm{C})), N$ was divided by the photosynthetic quotient of 1.4 for nitrate-based production (i.e., $N=1.4 \times N(\mathrm{C})$ ) (Laws, 1991). ${ }^{14} \mathrm{C}$ net primary production, $G\left({ }^{14} \mathrm{C}\right)$ (or $N\left({ }^{14} \mathrm{C}\right)$ ), was derived assuming $G=2.7 N\left({ }^{14} \mathrm{C}\right.$ ) (Bender et al., 1999; Marra, 2002).

\subsection{Entrainment of $\mathrm{O}_{2}\left(F_{\mathrm{e}}\right)$ due to changes in the depth of the mixed layer}

Previous approaches to estimate $F_{\mathrm{e}}$ (Emerson, 1987; Emerson et al., 2008) have used the concentration difference between thermocline and mixed layer. However, it is unclear how this concentration difference should be computed. Therefore, we derive the corresponding entrainment flux $\left(F_{\mathrm{e}}\right)$ in Appendix A, based on the $\mathrm{O}_{2}$ concentration gradient below the mixed layer:

$$
F_{\mathrm{e}}=-\left.\frac{1}{2} \frac{\left(\Delta z_{\mathrm{mix}}\right)^{2}}{\Delta t} \frac{\partial c\left(\mathrm{O}_{2}\right)}{\partial z}\right|_{\mathrm{oxy}},
$$

where the partial derivative is the gradient of oxygen in the oxycline, and $\Delta z_{\text {mix }}=z_{\text {mix, } 1}-z_{\text {mix }, 0}$ is the thickness of the entrained water column. For practical reasons we chose $z_{\text {mix, } 0}$ to correspond to 30 days before the cruise; $z_{\text {mix, } 1}$ corresponds to the mixed layer at the sampling time (i.e., $z_{\text {mix }}$ ). Positive $\Delta z_{\text {mix }}$ values represent deeper mixed layers than 30 days before our sampling time. Negative $\Delta z_{\text {mix }}$ values (mixed-layer shoaling) are ignored because they do not change the $\mathrm{O}_{2}$ concentration. Positive $F_{\mathrm{e}}$ values represent a decrease of mixed-layer $\mathrm{O}_{2}$ concentration due to entrainment of low-oxygenated waters.

The depth of the mixed layer 30 days before sampling was estimated from the monthly climatology of de Boyer Montégut et al. (2004). To correct for the difference between climatological and observed mixed-layer depths, $8 \mathrm{~m}$ were subtracted from the climatological values (Castro-Morales and Kaiser, 2012).

\subsection{Diapycnal eddy diffusion $\left(F_{\mathrm{v}}\right)$ across the base of the mixed layer}

$F_{\mathrm{v}}$ is calculated from Fick's first law of diffusion following:

$F_{\mathrm{v}}=-\left.K_{z} \frac{\partial c\left(\mathrm{O}_{2}\right)}{\partial z}\right|_{\mathrm{oxy}}$.

For $K_{z}$ (eddy diffusivity coefficient) we used a mean value of $\leq 1.0 \times 10^{-5} \mathrm{~m}^{2} \mathrm{~s}^{-1}$ based on the study of Howard et al. (2004) in Marguerite Bay during the Southern Ocean Global Ecosystem Dynamics program (GLOBEC) in autumn and winter 2001. The selected $K_{z}$ value is in close agreement to mean effective value of $1.1 \times 10^{-5} \mathrm{~m}^{2} \mathrm{~s}^{-1}$ derived by Law et al. (2003) during the $\mathrm{SF}_{6}$ tracer release Southern Ocean Iron Enrichment Experiment (SOIREE) in summer 1999 in the Australian sector of the SO (Law et al., 2003). The minimum and maximum wind speed values recorded during SOIREE (from 5 to $12 \mathrm{~m} \mathrm{~s}^{-1}$ ) were similar to the values recorded during our cruise (from 4.6 to $8 \mathrm{~m} \mathrm{~s}^{-1}$ ). The square of the buoyancy frequency $\left(v^{2}\right)$ during SOIREE was $10^{-3} \mathrm{~s}^{-2}$ for the seasonal pycnocline and up to $10^{-5} \mathrm{~s}^{-2}$ in the mixed layer towards the end of the experiment. During GLOBEC, the buoyancy frequency $\left(v^{2}\right)$ was $<10^{-4} \mathrm{~s}^{-2}$. The latter is consistent with $v^{2} \approx 10^{-4} \mathrm{~s}^{-2}$ found in this study (Sect. 4.4). Our estimates of $F_{\mathrm{v}}$ have an overall error of $20 \%$, which is mainly given by the $K_{z}$ (Law et al., 2003).

Depth profiles of $\mathrm{O}_{2} / \mathrm{Ar}$ are not available for our cruise. $\mathrm{O}_{2} / \mathrm{Ar}$ ratios should be used for the calculation of $F_{\mathrm{v}}$ and $F_{\mathrm{e}}$ associated with biological $\mathrm{O}_{2}$ fluxes. However, the error made by using $\mathrm{O}_{2}$ concentrations instead of $\mathrm{O}_{2} / \mathrm{Ar}$ is likely to be small, given that the vertical gradients in Ar saturation are probably small (Hamme and Severinghaus, 2007).

\subsection{Mixed-layer oxygen mass balance}

In this work we evaluate the influence of vertical fluxes on marine productivity estimates based on the $\mathrm{O}_{2}$ budget 
approach. The mixed-layer $\mathrm{O}_{2}$ mass balance, as described by Emerson et al. (2008), and considering steady state, can be rewritten as

$z_{\operatorname{mix}} \frac{\partial c\left(O_{2}\right)}{\partial t}=G-R-F_{\mathrm{g}}+F_{\mathrm{v}}+F_{\mathrm{e}}$,

where $G-R=N$ and refers to the gross photosynthetic $\mathrm{O}_{2}$ production minus the consumption oxygen by autotrophic and heterotrophic organisms present in the community. $N$ is approximated from $F_{\text {bio }}$. In this $\mathrm{O}_{2}$ balance budget, $F_{\text {bio }}$ is used to account for physical effects instead of $F_{\mathrm{g}}$. When the mass balance is expressed in terms of $\mathrm{O}_{2} / \mathrm{Ar}$, the firstorder time derivative term on the left-hand side of Eq. (7) is not present (Kaiser et al., 2005). We also do not consider the air-sea flux of $\mathrm{O}_{2}$ by bubbles as determining productivity from $\mathrm{O}_{2} / \mathrm{Ar}$ ratios removes the need to quantify by this effect (Hamme and Emerson, 2006). Thus, Eq. (7) yields to $N=G-R+F_{\mathrm{v}}+F_{\mathrm{e}}$.

\subsection{Estimates of gross photosynthetic $\mathrm{O}_{2}$ production} (G)

The method used here for estimates of $G$ has been thoroughly presented and discussed recently by Juranek and Quay (2013). Fundamentally, $G$ was constrained from the relative ${ }^{17} \mathrm{O} /{ }^{16} \mathrm{O}$ and ${ }^{18} \mathrm{O} /{ }^{16} \mathrm{O}$ isotope ratio differences between dissolved $\mathrm{O}_{2}$ and air $\mathrm{O}_{2}\left({ }^{17} \delta\right.$ and $\left.{ }^{18} \delta\right)$, measured on the same discrete samples as used for the $\mathrm{O}_{2} / \mathrm{Ar}$ calibration (Luz and Barkan, 2000).

The calculation follows the dual-delta method of Kaiser (2011), which assumes isotopic steady state and neglects horizontal and vertical mixing:

$G=k_{\mathrm{w}} c_{\mathrm{eq}} \frac{\left(1+{ }^{17} \varepsilon_{\mathrm{E}}\right) \frac{{ }^{17} \delta-17 \delta_{\mathrm{eq}}}{1+{ }^{17} \delta}-\gamma_{\mathrm{R}}\left(1+{ }^{18} \varepsilon_{\mathrm{E}}\right) \frac{18 \delta-1 \delta_{\mathrm{eq}}}{1+{ }^{18} \delta}+\Delta\left(\mathrm{O}_{2}\right)\left({ }^{17} \varepsilon_{\mathrm{E}}-\gamma_{\mathrm{R}}^{18} \varepsilon_{\mathrm{E}}\right)}{\frac{17 \delta_{\mathrm{P}}-17 \delta}{1+{ }^{17} \delta}-\gamma_{\mathrm{R}} \frac{18 \delta_{\mathrm{p}}-18 \delta}{1+{ }^{18} \delta}}$,

where $\varepsilon_{\mathrm{E}}$ is the kinetic isotope fractionation during $\mathrm{O}_{2}$ evasion, $\delta_{\mathrm{eq}}$ is the relative isotope ratio difference between $\mathrm{O}_{2}$ in equilibrium with the atmosphere and air $\mathrm{O}_{2}, \delta_{\mathrm{P}}$ is the relative isotope ratio difference between photosynthetic $\mathrm{O}_{2}$ and air $\mathrm{O}_{2}$, and $\gamma_{\mathrm{R}}={ }^{17} \varepsilon_{\mathrm{R}} /{ }^{18} \varepsilon_{\mathrm{R}}=0.5179$ is the ratio of the ${ }^{17} \mathrm{O} /{ }^{16} \mathrm{O}$ to the ${ }^{18} \mathrm{O} /{ }^{16} \mathrm{O}$ respiratory fractionation (Luz and Barkan, 2005). For ${ }^{18} \varepsilon_{\mathrm{E}}$ we use $-2.8 \%$ (Knox et al., 1992) and assume ${ }^{17} \varepsilon_{\mathrm{E}}=\left(1+{ }^{18} \varepsilon_{\mathrm{E}}\right)^{0.516}-1=-1.446 \%$. Temperature dependent $\delta_{\mathrm{eq}}$ values are calculated as ${ }^{18} \delta_{\mathrm{eq}}=e^{-0.00072951+0.42696 T / K}-1$ (Benson et al., 1979) and ${ }^{17} \delta_{\text {eq }}=\left(1+{ }^{18} \delta_{\text {eq }}\right)^{0.518} e^{\left(0.6 \theta /{ }^{\circ} \mathrm{C}+1.8\right) \mathrm{ppm}}-1$ (Luz and Barkan, 2009). The isotopic composition of photosynthetic $\mathrm{O}_{2}$ is based on that of Vienna Standard Mean Ocean Water (VSMOW) (Barkan and Luz, 2011; Kaiser and Abe, 2012), the relative ${ }^{17} \mathrm{O} /{ }^{16} \mathrm{O}$ difference between seawater and VSMOW of $-5 \mathrm{ppm}$ (Luz and Barkan, 2010) and measurements of the mean isotopic fractionation during photosynthesis by marine species of ${ }^{17} \varepsilon_{\mathrm{P}}=1.773 \%$ and ${ }^{18} \varepsilon_{\mathrm{P}}=3.389 \%$ (Eisenstadt et al., 2010).
A current disagreement in the literature regarding the isotope ratio difference between seawater and air $\mathrm{O}_{2}$ shows values between ${ }^{17} \delta_{w}=-11.888 \%{ }^{18} \delta_{w}=-23.324 \%$ (Barkan and Luz, 2011) and ${ }^{17} \delta_{w}=-12.107 \% o^{18} \delta_{w}=-23.647 \%$ o (Kaiser and Abe, 2012). Thus, we calculated two $G$ values $\left(G_{1}\right.$ and $\left.G_{2}\right)$ based on the two different sets of oxygen isotopic signatures resulting from photosynthetic activity $\left({ }^{17} \delta_{\mathrm{P}}\right.$ and ${ }^{18} \delta_{\mathrm{P}}$ values) taken from Table 3 rows $6 \mathrm{~m}\left({ }^{17} \delta_{\mathrm{P}}=-9.761 \% \mathrm{o}^{18} \delta_{\mathrm{P}}=-19.301 \%\right.$ o $)$ and $7 \mathrm{~m}$ $\left({ }^{17} \delta_{\mathrm{P}}=-9.980 \%{ }^{18} \delta_{\mathrm{P}}=-19.625 \%\right.$ o $)$ in Kaiser and Abe (2012).

The ${ }^{17} \mathrm{O}$ isotope excess $\left({ }^{17} \Delta\right)$ of dissolved oxygen is also calculated according to the simplified form: ${ }^{17} \Delta \equiv{ }^{17} \delta-0.5179^{18} \delta$ (Eq. 4 in Kaiser, 2011). Although we no longer use ${ }^{17} \Delta$ to calculate $G$ (Kaiser, 2011), we report our results for presentational purposes.

The standard error in our ${ }^{17} \Delta$ values is $3 \mathrm{ppm}$, with a population standard deviation of $9 \mathrm{ppm}$ for the 11 aliquots of airsaturated water analyzed in the laboratory. The uncertainty in $G$ estimated from the dual-delta method is partly due to the gas transfer coefficient, which is about $15 \%$ for typical oceanic mixed-layer conditions, and partly due to uncertainty in the isotope measurements.

Due to the lack of oxygen triple isotope measurements in waters below the mixed layer, corrections by $F_{\mathrm{v}}$ and $F_{\mathrm{e}}$ are not applied here to the $G$ estimates. Furthermore, since respiration in waters below the mixed layer has little effect on the calculation of gross oxygen production using oxygen triple isotopes, we expect $G$ to be less affected by entrainment than $N$.

\section{Results}

We present the results separately for WSIZ and POOZ. The WSIZ comprised two areas: (1) the coast of Wilkins Ice Shelf (WIS, CTD stations 1 to 36) south of the entrance to Marguerite Bay, and (2) Marguerite Bay 1 (MB1, CTD stations 178 to 198) close to the coast of Alexander Island. The POOZ comprised three areas: (1) Belgica Trough (BT, CTD stations 90 to 135), (2) Marguerite Bay 2 (MB2, CTD stations 199 to 213) in the northern part of the entrance to Marguerite Bay and towards the coast of Adelaide Island, and (3) west of Adelaide Island (WAI, CTD stations 214 to 252) in the northernmost part of the sampling area. The Marguerite Bay region was divided into two areas due to the contrasting distributions of the measured variables (Fig. 1).

Locations of the main water masses over depth in the area of study were identified with a T-S diagram (Fig. 2). Most of the water column contained AASW, followed by the more oxygenated MW. We also evaluated the relationship between the $c\left(\mathrm{O}_{2}\right)$ and $\theta$ (in the entire water column, Fig. 4a; and only in the mixed layer Fig. 4c) and $S$ (Fig. 4 b and d). 


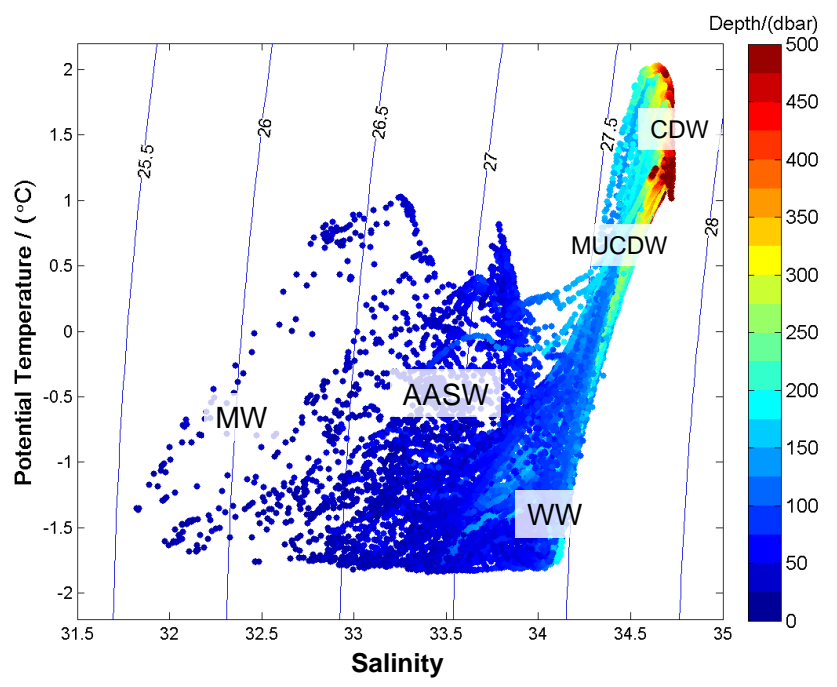

Fig. 2. T-S diagram derived from CTD profiles for identification of main water masses in the Bellingshausen Sea. Colors correspond to depth. MW, melt water; AASW, Antarctic surface water; WW, winter water; MUCDW, modified upper circumpolar deep water; and CDW, circumpolar deep water. Contours of potential density in sigma units $\left(\mathrm{kg} \mathrm{m}^{-3}-1000\right)$ are shown.

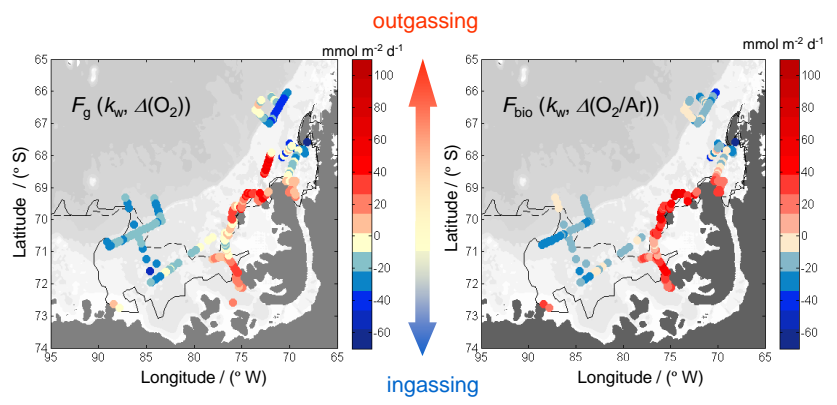

Fig. 3. Sea-to-air $\mathrm{O}_{2}$ flux $\left(F_{\mathrm{g}}\right.$, left panel) and biological $\mathrm{O}_{2}$ flux ( $F_{\text {bio }}$, right panel), along the cruise track in the Bellingshausen Sea. The MIZ at the beginning (solid black contour) and at the end (dashed black contour) of the JR165 cruise are shown.

\subsection{Variation of $\Delta\left(\mathrm{O}_{2} / \mathrm{Ar}\right)$ in relation to the MIZ}

The approximate location of the MIZ is shown in Fig. 1, and it was defined by a threshold sea ice concentration of $30 \%$. Sea ice concentrations were obtained from $1 \mathrm{~km}$ resolution ENVISAT ASAR-E/ESA images (http://www.seaice.dk) at the beginning (3 March 2007) and end (4 April 2007) of the cruise. The change of the MIZ position between $95^{\circ}$ and $87^{\circ} \mathrm{W}$ and $76^{\circ}$ and $65^{\circ} \mathrm{W}$ was almost negligible. In contrast, a sea ice advance of about $215 \mathrm{~km}$ was observed in the central part of the area of study between $75^{\circ}$ and $87^{\circ} \mathrm{W}$, from the coast of Fletcher Peninsula, Allison Peninsula and Eltanin Bay towards the shelf break in Belgica Trough (Fig. 1). The rate of sea ice advance during the sampling period was about $5.6 \mathrm{~km} \mathrm{~d}^{-1}$. This shows the formation of new ice with a fur- a

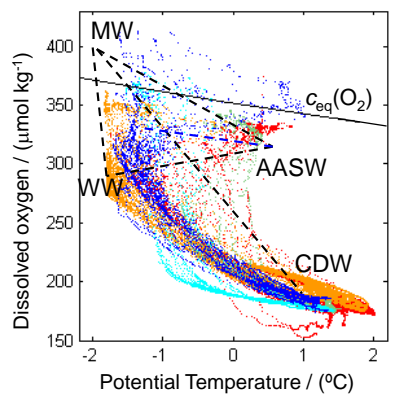

b
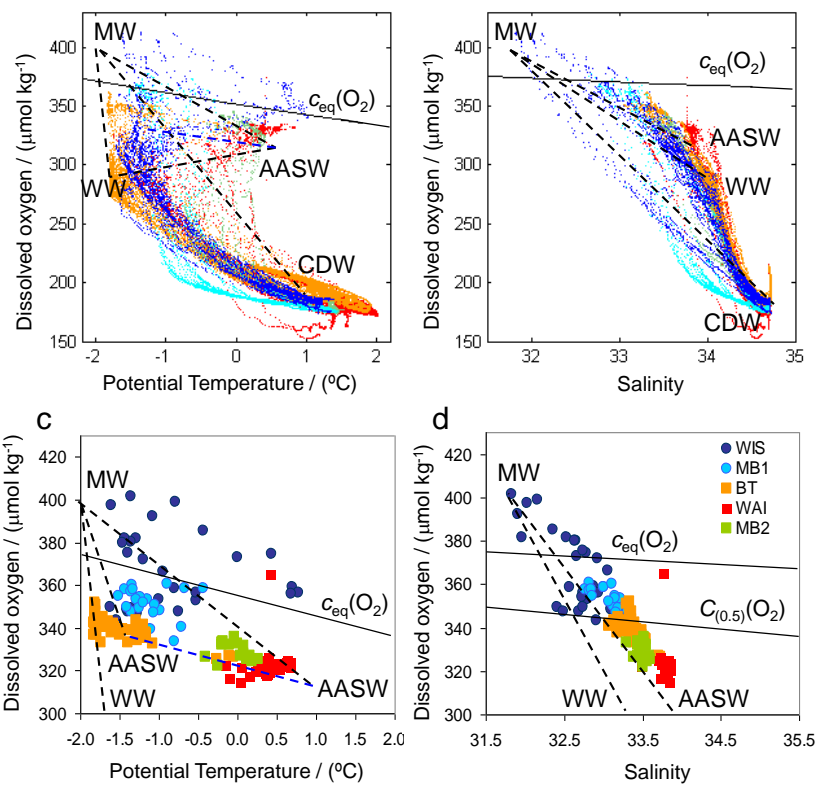

Fig. 4. Plots of dissolved oxygen against potential temperature and salinity. (a) and (b) include all measurements for identification of water masses; (c) and (d) only show mixed-layer data. Dashed lines correspond to the mixing lines given by the end points of properties for the different water masses. Solid lines show the $\mathrm{O}_{2}$ concentrations at air saturation at (a, c) constant salinity of 33.5 and $(\mathbf{b}, \mathbf{d})$ constant temperature at seawater surface freezing point $\left(-1.8^{\circ} \mathrm{C}\right)$. Note in panel (c) the blue dashed line represents the wide range of temperatures that characterize the AASW, extending from colder $\left(<-1.0^{\circ} \mathrm{C}\right)$ to warmer $\left(>0.5^{\circ} \mathrm{C}\right)$ waters. (d) WIS and MB1 are supersaturated in $\mathrm{O}_{2}$, considering the range of temperature dominated in the mixed layer of these areas $\left(-1.8<\theta<0.5^{\circ} \mathrm{C}\right) . c\left(\mathrm{O}_{2}\right)$ at these constant temperatures is depicted $\left(c_{\mathrm{eq}}\left(\mathrm{O}_{2}\right)\right.$ at $-1.8^{\circ} \mathrm{C}$ and $c_{(0.5)}\left(\mathrm{O}_{2}\right)$ at $\left.0.5^{\circ} \mathrm{C}\right)$.

ther advance of the MIZ towards the shelf break during the beginning of autumn.

During the cruise we made visual observations of the sea ice cover. Most of the stations located within the WSIZ presented open water conditions, with most of the first-year ice melted away towards the end of summer, and sparse ice floes can be seen. The only exception was station 22, located southwest of Charcot Island, where the ocean was covered predominantly by fast ice. The underway system onboard was shut down during this station and no dissolved gas data were acquired.

The spatial distribution of $\mathrm{O}_{2}$ and $\mathrm{O}_{2} / \mathrm{Ar}$ supersaturations in the WSIZ and POOZ was heterogeneous and clearly associated with the location of the MIZ. In the WSIZ, $\Delta\left(\mathrm{O}_{2}\right)$ and $\Delta\left(\mathrm{O}_{2} / \mathrm{Ar}\right)$ were $(2.4 \pm 3.0) \%$ and $(5.7 \pm 3.4) \%$, respectively (average $\pm 1 \sigma$ and hereafter). In the POOZ, undersaturation prevailed, with $\Delta\left(\mathrm{O}_{2}\right)=(-2.0 \pm 0.9) \%$ and $\Delta\left(\mathrm{O}_{2} / \mathrm{Ar}\right)=(-1.6 \pm 0.9) \%$. In the MB1 area, $\Delta\left(\mathrm{O}_{2} / \mathrm{Ar}\right)$ was positive at $(5.3 \pm 2.9) \%$. In contrast, $\Delta\left(\mathrm{O}_{2} / \mathrm{Ar}\right)$ in $\mathrm{MB} 2$ was 
Table 1. Average ( \pm 1 standard deviation) of the main measured and calculated variables in the mixed layer for cruise JR165 (summer 2007, Bellingshausen Sea). Results are categorized by area: WIS, Wilkins Ice Shelf; MB1, Marguerite Bay 1; BT, Belgica Trough; MB2, Marguerite Bay 2 and WAI, west of Adelaide Island (CTD stations in between the ones presented here are not included). $\Delta z_{\mathrm{mix}}$ is the change in mixed-layer depth over $\Delta t=30$ days prior to sampling. Positive values indicate a deepening of the mixed layer. $v^{2}$ is the Brunt-Väisälä frequency based on the density change in the top $50 \mathrm{~m}$ of the water column.

\begin{tabular}{|c|c|c|c|c|c|c|c|c|c|c|c|}
\hline Area & $\begin{array}{c}\text { CTD } \\
\text { stations }\end{array}$ & $\theta /{ }^{\circ} \mathrm{C}$ & $S$ & $\begin{array}{c}c\left(\mathrm{O}_{2}\right) / \\
\left(\mu \mathrm{mol} \mathrm{kg} \mathrm{kg}^{-1}\right)\end{array}$ & $\Delta\left(\mathrm{O}_{2}\right) / \%$ & $\Delta\left(\mathrm{O}_{2} / \mathrm{Ar}\right) / \%$ & $k_{w} /\left(\mathrm{md}^{-1}\right)$ & $\Delta z_{\text {mix }} / \mathrm{m}$ & $z_{\text {mix }} / \mathrm{m}$ & $\begin{array}{c}\left(\Delta z_{\operatorname{mix}} / \Delta t\right) / \\
\left(\mathrm{m} \mathrm{d}^{-1}\right)\end{array}$ & $\begin{array}{l}10^{4} v^{2} / \\
\left(\mathrm{s}^{-2}\right)\end{array}$ \\
\hline \multicolumn{12}{|c|}{ Winter sea ice zone (WSIZ) } \\
\hline MB1 & $178-198$ & $-1.1 \pm 0.2$ & $33.0 \pm 0.2$ & $352 \pm 7$ & $1.9 \pm 2.5$ & $5.3 \pm 2.9$ & $1.2 \pm 0.3$ & $4 \pm 7$ & $18 \pm 7$ & 0.1 & $1.2 \pm 0.3$ \\
\hline \multicolumn{12}{|c|}{ Permanent open ocean zone (POOZ) } \\
\hline
\end{tabular}

negative at $(-1.2 \pm 0.9) \%$. During the sampling period, the MIZ at the entrance of Marguerite Bay remained close to Alexander Island and towards George VI ice shelf (Fig. 1). Its location coincides with the contrasting $\Delta\left(\mathrm{O}_{2} / \mathrm{Ar}\right)$ distribution between MB1 and MB2.

$F_{\text {bio }}$ reflects the observed heterogeneity in $\Delta\left(\mathrm{O}_{2} / \mathrm{Ar}\right)$ (Fig. 3). High biological $\mathrm{O}_{2}$ fluxes were observed in the WSIZ, on average $(27 \pm 14) \mathrm{mmol} \mathrm{m}^{-2} \mathrm{~d}^{-1}$. In contrast, $\mathrm{O}_{2} / \mathrm{Ar}$ undersaturations caused negative $F_{\text {bio }}$ in the POOZ, on average $(-16 \pm 9) \mathrm{mmol} \mathrm{m}^{-2} \mathrm{~d}^{-1}$ (Table 2).

In the following sections, the properties of the upper $200 \mathrm{~m}$ are presented for the WSIZ (Sect. 4.2) and for the POOZ (Sect. 4.3). The stability of the water column is discussed (Sect. 4.4) and estimates of $F_{\mathrm{V}}$ and $F_{\mathrm{e}}$ are shown in Sect. 4.5. Gross oxygen production estimates are shown in Sect. 4.6, along with corresponding $f$ ratios based on oxygen $(f=N / G)$. Average values for various properties are summarized in Tables 1 and 2.

\subsection{Winter sea ice zone (WSIZ)}

In the WSIZ, the WIS area was sampled at the beginning of the survey during late summer ( 3 to 8 March 2007), while the MB1 area was sampled 28 days later representing early autumn (31 March to 2 April 2007). Despite the different sampling periods, the characteristics of the water column remained similar. In the WSIZ, MW dominated the top $80 \mathrm{~m}$, including the mixed layer. MW was characterized by colder $\left(-1.8^{\circ} \mathrm{C}\right)$, fresher $(S<31.8)$ and more $\mathrm{O}_{2}$-supersaturated water $\left(\Delta\left(\mathrm{O}_{2}\right)\right.$ up to $\left.12 \%\right)$ than the waters below (Fig. $4 \mathrm{c}$ and d). Underneath, the water column was dominated by the saltier (33.5 to 34$)$ and colder portion $\left(-1.8\right.$ to $\left.-1.0^{\circ} \mathrm{C}\right)$ of AASW.

The mixed-layer depth $\left(z_{\mathrm{mix}}\right)$ was generally shallow with a mean of $(17 \pm 6) \mathrm{m}$. In the WIS, temperature inversions occurred in the upper $50 \mathrm{~m}$. The average change of temperature within the inversions ranged from -1 to $1^{\circ} \mathrm{C}$ over a few tens of meters. It is possible that the inversions were the result of the horizontal advection of sea ice MW mainly from the coast of Charcot Island. Less MW influence was observed for Latady Island and Beethoven Peninsula, in the western and southern parts of WIS, respectively, and for Alexander Island in the north. AASW dominated the top $180 \mathrm{~m}$ near the coasts of Latady Island, Beethoven Peninsula and Alexander Island.

No remnant WW was found in the upper $100 \mathrm{~m}$; this was expected as WW is replaced by AASW and MW during the summer. AASW was lying above modified upper circumpolar deep water (MUCDW, Fig. 2), with the latter located below $180 \mathrm{~m}$ and characterized by being warmer $\left(0.5\right.$ to $\left.0.8^{\circ} \mathrm{C}\right)$, saltier $(S>34)$ and undersaturated in $\mathrm{O}_{2}$ by as much as $40 \%$.

In the MB1 area, MW in the mixed layer appeared to originate from sea ice melt close to Alexander Island. MW extended horizontally and towards the northeast up to $31 \mathrm{~km}$ (from stations 194 to 199), and vertically up to $100 \mathrm{~m}$ depth. In the MB2 area between stations 199 and 201, MW penetrated as deep as $150 \mathrm{~m}$. AASW dominated the mixed layer for the rest of the section towards Adelaide Island.

The monthly mean wind direction showed predominant southerly winds over the WIS and MB areas during February, March and April 2007. The weighted gas exchange coefficient $\left(k_{w}\right)$ (Reuer et al., 2007; Sweeney et al., 2007) was 2 times lower in the WSIZ at $(1.4 \pm 0.3) \mathrm{m} \mathrm{d}^{-1}$ than in the $\mathrm{POOZ}$ at $(2.8 \pm 0.3) \mathrm{m} \mathrm{d}^{-1}$.

Positive net sea-to-air $\mathrm{O}_{2}$ fluxes of $(14 \pm 7)$ and $(6 \pm 10) \mathrm{mmol} \mathrm{m}^{-2} \mathrm{~d}^{-1}$ were observed for WIS and MB1, respectively. The corresponding $F_{\text {bio }}$ values were $(38 \pm 22) \mathrm{mmol} \mathrm{m}^{-2} \mathrm{~d}^{-1}$ for WIS and $(21 \pm 11) \mathrm{mmol} \mathrm{m}^{-2} \mathrm{~d}^{-1}$ for MB1 (Table 2 and Fig. 3).

\subsection{Permanent open ocean zone (POOZ)}

The observed MIZ advance towards the shelf break by the end of our cruise affected mainly the BT area, which was not fully sampled for underway $\mathrm{O}_{2}$ and $\mathrm{O}_{2} / \mathrm{Ar}$ (see Fig. 3), while 
Table 2. Mixed-layer net and gross oxygen production and related variables. Positive $F_{\mathrm{g}}, F_{\mathrm{V}}, F_{\mathrm{e}}$ and $F_{\text {bio }}$ values mean a net loss of oxygen from the mixed layer. Net community production is calculated as $N=F_{\text {bio }}+F_{\mathrm{v}}+F_{\mathrm{e}}$.

\begin{tabular}{|c|c|c|c|c|c|c|c|c|c|c|c|c|c|}
\hline Area & $\begin{array}{c}F_{\mathrm{g}} / \\
\left(\mathrm{mmol} \mathrm{m}^{-2} \mathrm{~d}^{-1}\right) \\
\end{array}$ & $\begin{array}{c}F_{\text {bio }} / \\
\left(\mathrm{mmol} \mathrm{m}^{-2} \mathrm{~d}^{-1}\right)\end{array}$ & $\begin{array}{c}F_{\mathrm{V}} / \\
\left(\mathrm{mmol} \mathrm{m}^{-2} \mathrm{~d}^{-1}\right) \\
\end{array}$ & $\begin{array}{c}F_{\mathrm{e}} / \\
\left(\mathrm{mmol} \mathrm{m}^{-2} \mathrm{~d}^{-1}\right) \\
\end{array}$ & $\begin{array}{c}/ \\
\left(\mathrm{mmol} \mathrm{m}^{-2} \mathrm{~d}^{-1}\right) \\
\end{array}$ & $\begin{array}{l}{ }^{17} \Delta / \\
\mathrm{ppm}\end{array}$ & $\begin{array}{c}G_{1} / \\
\left(\mathrm{mmol} \mathrm{m}^{-2} \mathrm{~d}^{-1}\right)^{\mathrm{a}} \\
\end{array}$ & $\begin{array}{c}G_{2} / \\
\left(\mathrm{mmol} \mathrm{m}^{-2} \mathrm{~d}^{-1}\right)^{\mathrm{b}} \\
\end{array}$ & $\begin{array}{l}f_{1}= \\
N / G_{1}\end{array}$ & $\begin{array}{c}f_{2}= \\
N / G_{2}\end{array}$ & $\begin{array}{c}N(\mathrm{C}) / \\
\left(\mathrm{mmol} \mathrm{m}^{-2} \mathrm{~d}^{-1}\right) \\
\end{array}$ & $\begin{array}{c}G\left({ }^{14} \mathrm{C}\right) / \\
\left(\mathrm{mmol} \mathrm{m}^{-2} \mathrm{~d}^{-1}\right)\end{array}$ & $\begin{array}{c}f=N(\mathrm{C}) / \\
\mathrm{G}\left({ }^{14} \mathrm{C}\right)\end{array}$ \\
\hline \multicolumn{14}{|c|}{ Sea ice zone (SIZ) } \\
\hline WIS & $14 \pm 7$ & $38 \pm 22$ & $1.5 \pm 1.1$ & 0 & $39 \pm 22$ & $56 \pm 25$ & $231 \pm 99$ & $161 \pm 58$ & 0.17 & 0.24 & 28 & 73 & 0.39 \\
\hline MB1 & $6 \pm 10$ & $21 \pm 11$ & $3.1 \pm 3.4$ & $5 \pm 6$ & $29 \pm 13$ & $58 \pm 9$ & $181 \pm 41$ & $130 \pm 29$ & 0.16 & 0.22 & 21 & 58 & 0.37 \\
\hline \multicolumn{14}{|c|}{ Permanent open ocean zone (POOZ) } \\
\hline BT & $-23 \pm 4$ & $-18 \pm 7$ & $1.0 \pm 0.9$ & $6 \pm 5$ & $-12 \pm 9$ & $28 \pm 9$ & $139 \pm 56$ & $103 \pm 40$ & $(<0)$ & $(<0)$ & $(-8)$ & 45 & $(<0)$ \\
\hline MB2 & $-13 \pm 10$ & $-12 \pm 11$ & $1.1 \pm 1.9$ & $15 \pm 22$ & $4 \pm 25$ & $25 \pm 7$ & $157 \pm 31$ & $118 \pm 23$ & 0.02 & 0.03 & 3 & 51 & 0.05 \\
\hline WAI & $-23 \pm 15$ & $-20 \pm 12$ & $1.6 \pm 3.3$ & $22 \pm 15$ & $4 \pm 20$ & $24 \pm 10$ & $157 \pm 61$ & $118 \pm 45$ & 0.02 & 0.03 & 3 & 51 & 0.05 \\
\hline
\end{tabular}

${ }^{\text {a Calculated using }}{ }^{17} \delta_{\mathrm{P}}=-9.761 \%$ and ${ }^{18} \delta_{\mathrm{P}}=-19.301 \%$ (Barkan and Luz, 2011; taken from Table 3 row $6 \mathrm{~m}$ in Kaiser and Abe, 2012).

${ }^{\mathrm{b}}$ Calculated using ${ }^{17} \delta_{\mathrm{P}}=-9.980 \%$ and ${ }^{18} \delta_{\mathrm{P}}=-19.625 \%$ (Kaiser and Abe, 2012; taken from Table 3 row $7 \mathrm{~m}$ in Kaiser and Abe, 2012).

the WAI and MB2 areas remained open during the sampling period.

In agreement with Vernet et al. (2008), we found that the mixed-layer depth increased with distance from the coast in the WAP region. The mixed-layer depth in the POOZ was on average $20 \mathrm{~m}$ deeper than in the WSIZ. Deeper and more variable mixed layers were observed in the WAI area $(51 \pm 14 \mathrm{~m})$, while shallower mixed layers were found in the MB2 (34 $\pm 11 \mathrm{~m})$ and the BT $(28 \pm 7 \mathrm{~m})$ areas. This could be due to the stronger influence of northerly winds in the WAI area. The wind stress was weaker towards the coast, in the more topographically protected areas and towards the central part of the Bellingshausen Sea in the BT area during March and April.

The areas away from the coast had less influence of MW from the ice shelves, coastline and glaciers. The vertical profiles of temperature, salinity and dissolved oxygen indicate that the mixed layer was dominated by AASW. The latter is characterized by a wide range of temperatures (from the coldest at $-1.4^{\circ} \mathrm{C}$ in the BT away from the MW influence, followed by the MB2 with $0{ }^{\circ} \mathrm{C}$, and finally WAI with $0.4{ }^{\circ} \mathrm{C}$ ) (Fig. 4c). A consistent range of potential density between 1026.6 to $1027.2 \mathrm{~kg} \mathrm{~m}^{-3}$ was observed as a result of wellmixed upper water in this zone. AASW extended down to $180 \mathrm{~m}$ depth, above MUCDW. In agreement with Garibotti et al. (2003), the remnant of the WW was present between 50 and $100 \mathrm{~m}$ below the mixed layer and the seasonal pycnocline, where $\mathrm{O}_{2}$ undersaturation levels up to $30 \%$ were observed. A transect across the WAI showed WW beneath the mixed layer defined by the surface distribution of $\mathrm{O}_{2}$ (Fig. 5).

In the POOZ, total $\mathrm{O}_{2}$ was undersaturated, as was the biologically produced $\mathrm{O}_{2}$. The average $\Delta\left(\mathrm{O}_{2}\right)$ was $(-2.0 \pm 0.9) \%$, corresponding to an $\mathrm{O}_{2}$ concentration between 310 to $350 \mu \mathrm{mol} \mathrm{kg}-1$, and $(-1.6 \pm 0.9) \%$ for $\Delta\left(\mathrm{O}_{2} / \mathrm{Ar}\right)$ (Table 1). The $\mathrm{O}_{2}$ concentration in the AASW was mainly close to saturation; however, it was slightly undersaturated at the higher temperature and salinity limits $\left(1^{\circ} \mathrm{C}\right.$ and 33.7; Serebrennikova and Fanning, 2004). The lowest mixed-layer $\Delta\left(\mathrm{O}_{2}\right)$ was $-4 \%$ in the WAI area. The negative $\Delta\left(\mathrm{O}_{2} / \mathrm{Ar}\right)$ values indicated net heterotrophy and/or mixing with undersaturated waters.

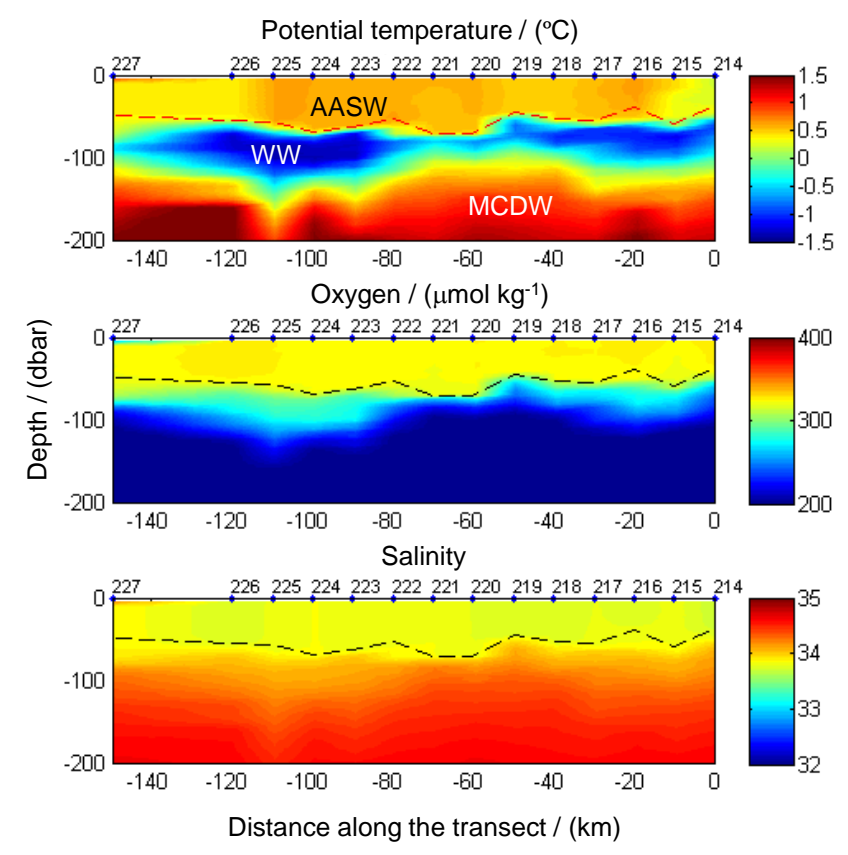

Fig. 5. Vertical sections showing the distribution of water masses for stations 214 to 227 in the west of the Adelaide Island area. The dashed horizontal line represents the bottom of the mixed layer as defined by the distribution of dissolved oxygen. AASW dominates the mixed layer, with WW beneath it and MCDW filling depths from $150 \mathrm{~m}$.

The gas transfer coefficient was on average two times higher in the POOZ than in the WSIZ. The average $F_{\mathrm{g}}$ was $(-20 \pm 10) \mathrm{mmol} \mathrm{m}^{-2} \mathrm{~d}^{-1}$, and the average $F_{\text {bio }}$ was $(-17 \pm 10) \mathrm{mmol} \mathrm{m}^{-2} \mathrm{~d}^{-1}$ (Table 2 and Fig. 3 ).

\subsection{Stability of the water column}

As a measure of water column stability, the square of the buoyancy frequency (Brunt-Väisälä frequency) was calculated as $v^{2} \equiv-g / \rho \mathrm{d} \rho / \mathrm{d} z$, where $g$ is the acceleration due to gravity $\left(9.81 \mathrm{~m} \mathrm{~s}^{-2}\right)$ and $\rho$ the average seawater density in the top $50 \mathrm{~m}$ of the water column; these are multiplied by the change in density over the same depth range $(\mathrm{d} \rho / \mathrm{d} z)$. We identified $50 \mathrm{~m}$ as the upper limit of the WW, consistent with 


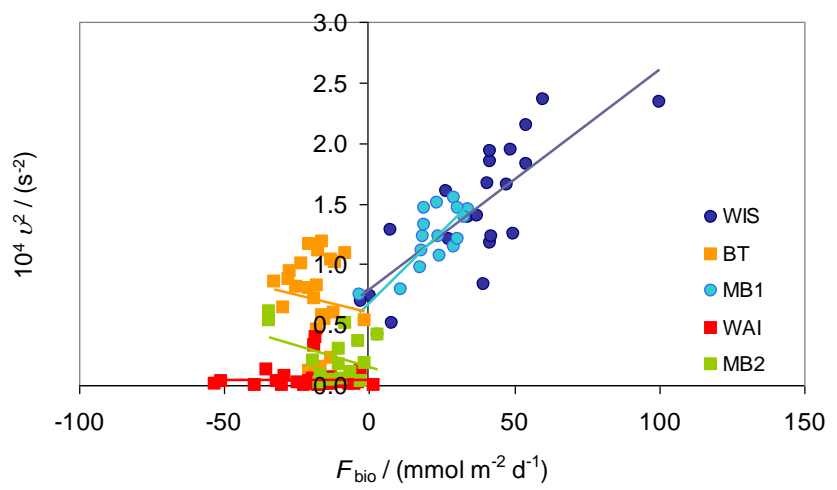

Fig. 6. Correlation between the square of the Brunt-Väisälä frequency $\left(10^{4} v^{2}\right)$ and the biological oxygen flux $\left(F_{\text {bio }}\right)$ : dark and light blue circles represent the stations located in the WIS and MB1 areas (WSIZ); squares in orange, green and red are the stations for the BT, MB2 and WAI areas, respectively, in the POOZ.

Garibotti et al. (2003). The upper $50 \mathrm{~m}$ of the water column in the continental shelf of the WAP experience the largest spatial variability due to local environmental processes (Hofmann and Klinck, 1998).

$v^{2}$ in the POOZ was four times lower than in the WSIZ (Table 1). $v^{2}$ averaged $1.5 \times 10^{-4} \mathrm{~s}^{-2}$ and $1.2 \times 10^{-4} \mathrm{~s}^{-2}$ in WIS and MB1, compared to $0.8 \times 10^{-4} \mathrm{~s}^{-2}, 0.2 \times 10^{-4} \mathrm{~s}^{-2}$ and $0.04 \times 10^{-4} \mathrm{~s}^{-2}$, in BT, MB2 and WAI, respectively. A positive correlation between $v^{2}$ and $F_{\text {bio }}$ was observed in the WSIZ areas $\left(R^{2}=0.61\right.$ for WIS, and $R^{2}=0.63$ for MB1) (Fig. 6), consistent with previous observations of higher biological production associated with higher water column stability (i.e., Garibotti et al., 2003, 2005b; Smith et al., 1998; Vernet et al., 2008).

\subsection{Calculation of $N$ corrected by $F_{\mathrm{v}}$ and $F_{\mathrm{e}}$}

Often, $F_{\text {bio }}$ is assumed to equal mixed-layer $N$ (Hendricks et al., 2004; Reuer et al., 2007). However, as the values for $F_{\mathrm{v}}$ and $F_{\mathrm{e}}$ in Table 2 show, vertical mixing cannot be disregarded in the calculation of mixed-layer $N$ in this region. Here we estimate $N$ as the sum of $F_{\text {bio }}, F_{\mathrm{e}}$ and $F_{\mathrm{v}}$, neglecting horizontal fluxes and assuming steady state. It is important to note that in all vertical profiles, the oxygen concentration below the mixed layer was consistently lower than in surface waters.

In the WSIZ areas, $F_{\mathrm{v}}$ was on average $(1.5 \pm 1.1) \mathrm{mmol} \mathrm{m}^{-2} \mathrm{~d}^{-1}$ for WIS and $(3.1 \pm 3.4) \mathrm{mmol} \mathrm{m}^{-2} \mathrm{~d}^{-1}$ for MB1. The positive $F_{\mathrm{V}}$ values mean that there is a net loss of $\mathrm{O}_{2}$ from the mixed layer to the upper thermocline below. For the calculation of $F_{\mathrm{e}}$, we estimated changes in mixed-layer depth from climatological data (de Boyer Montégut et al., 2004). According to these data, the WIS mixed layer may have been $10 \mathrm{~m}$ deeper 30 days prior to the occupation of this cruise section. Thus, $F_{\mathrm{e}}$ is zero because entrainment only occurs when the

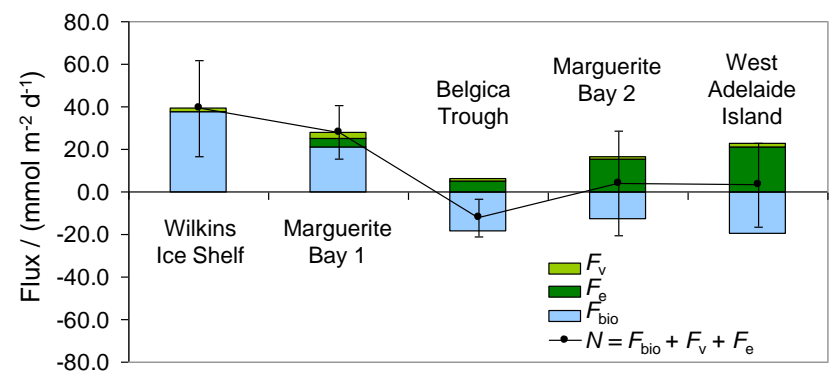

Fig. 7. Representation of $\mathrm{O}_{2}$ fluxes $\left(F_{\mathrm{e}}, F_{\mathrm{V}}\right.$ and $F_{\text {bio }}$ in $\left.\mathrm{mmol} \mathrm{m} \mathrm{d}^{-2} \mathrm{~d}^{-1}\right)$ in the WSIZ and POOZ. Positive values indicate flux out of the mixed layer. The total $N$ is depicted as a black line, with corresponding error bars representing the error after quantification of physical effects.

mixed layer deepens. With $F_{\mathrm{v}}=1.5 \mathrm{mmol} \mathrm{m}^{-2} \mathrm{~d}^{-1}$, vertical mixing is negligible in the WIS and $N=39 \mathrm{mmol} \mathrm{m}^{-2} \mathrm{~d}^{-1}$ is almost equal to $F_{\text {bio }}=38 \mathrm{mmol} \mathrm{m}^{-2} \mathrm{~d}^{-1}$. In contrast, the mixed layer in the MB1 area may have deepened by $5 \mathrm{~m}$ to $19 \mathrm{~m} . F_{\mathrm{e}}$ and $F_{\mathrm{v}}$ in this area are $(5 \pm 6)$ and $(3.1 \pm 3.4) \mathrm{mmol} \mathrm{m}^{-2} \mathrm{~d}^{-1}$, respectively, suggesting $\mathrm{O}_{2}$ loss from the mixed layer. $N$ would therefore be about $1 / 3$ higher than the observed $F_{\text {bio }}$ value of $21 \mathrm{mmol} \mathrm{m}^{-2} \mathrm{~d}^{-1}$ and equal to approximately $29 \mathrm{mmol} \mathrm{m}^{-2} \mathrm{~d}^{-1}$. Thus, the WSIZ is characterized by net autotrophy during the sampling period.

$F_{\mathrm{v}}$ was similar in all areas of the POOZ: $(1.0 \pm 0.9) \mathrm{mmol} \mathrm{m}^{-2} \mathrm{~d}^{-1}$ for BT, $(1.1 \pm 1.9) \mathrm{mmol} \mathrm{m}^{-2} \mathrm{~d}^{-1}$ for MB2 and (1.6 \pm 3.3$) \mathrm{mmol} \mathrm{m}^{-2} \mathrm{~d}^{-1}$ for WAI (Table 2). According to the climatological data, $z_{\text {mix }}$ was deeper at the time of sampling than 30 days before (Table 1) and the deepening occurred mainly within the extension of the AASW down into the water column in the BT and MB2 areas. However, in the WAI area where the deeper mixed layers during the sampling period were observed, the estimated deepening of the mixed layer by $4 \mathrm{~m}$ would reach the extension of the WW. $N$, corrected for $F_{\mathrm{v}}$ and $F_{\mathrm{e}}$, was therefore $4 \mathrm{mmol} \mathrm{m}^{-2} \mathrm{~d}^{-1}$ in MB2 and WAI. Only the BT area, which is the furthest offshore, may have shown actual heterotrophy in the mixed layer with $N$ of $(-12 \pm 9) \mathrm{mmol} \mathrm{m}^{-2} \mathrm{~d}^{-1}$.

The MB2 and WAI areas, rather than being net heterotrophic, may actually have been neutral or slightly autotrophic. In fact, the BT area may be the only net heterotrophic region after correcting for the physical effects. The advection of subsurface waters by entrainment appeared to have a higher effect on $N$ in the MB2 and WAI than in BT by mixing and diluting mixed-layer waters with lowoxygenated subsurface waters (Table 2). The total fluxes for each area are depicted in Fig. 7.

\section{6 $G$ and ${ }^{17} \mathrm{O}$ excess in dissolved $\mathrm{O}_{2}$}

The highest ${ }^{17} \Delta$ values in the area of study were found in the WIS and MB1 area, ranging between 31 to 81 ppm (Table 2). 


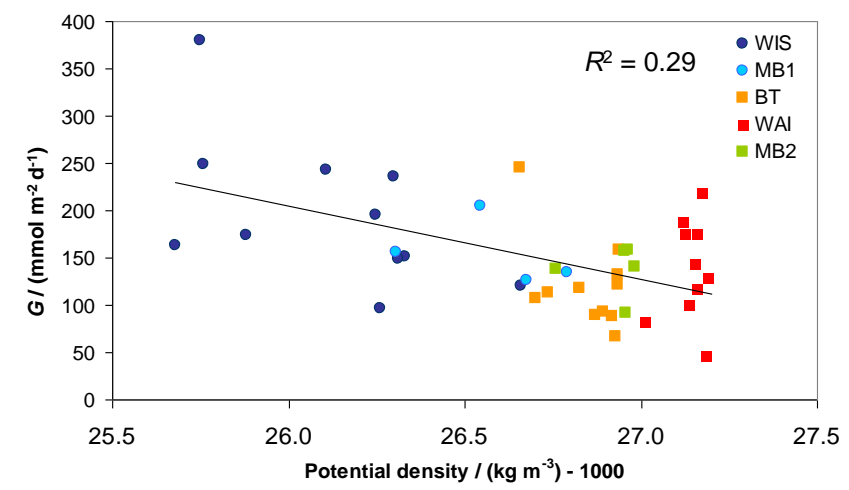

Fig. 8. Linear correlation $\left(R^{2}=0.29\right)$ between potential density and mixed-layer average $G$.

On average, the ${ }^{17} \Delta$ values were two times smaller in POOZ at (26 \pm 9$)$ ppm than in WSIZ at (57 \pm 17$)$ ppm.

$G$ is calculated from oxygen triple isotope measurements. From the two $G$ values $\left(G_{1}\right.$ to $G_{2}$ given in Table 2$)$ calculated using two different pairs of ${ }^{17} \delta_{\mathrm{P}}$ and ${ }^{18} \delta_{\mathrm{P}}$ (Kaiser and Abe, 2012), those based on Kaiser and Abe (2012) are about $40 \%$ higher than the ones based on Barkan and Luz (2011) (Fig. 9). For the purposes of our discussion we use the mean of these two $G$ values.

The mean of the $G$ values is higher in WSIZ $\left(176 \pm 70 \mathrm{mmol} \mathrm{m}^{-2} \mathrm{~d}^{-1}\right)$ than in POOZ $\left(132 \pm 49 \mathrm{mmol} \mathrm{m}^{-2} \mathrm{~d}^{-1}\right)$. Sea ice melt water may have delivered enough nutrients to maintain higher productivity levels in the WSIZ areas, and at the same time contributed to increase the stratification of the water column. To evaluate this, mixed-layer potential density was compared to $G$ (Fig. 8). A negative correlation $\left(R^{2}=0.29\right)$ indicated that low potential densities (from 1025.7 to $1026.8 \mathrm{~kg} \mathrm{~m}^{-3}$ ) generally corresponded with high mixed-layer $G$ values. This is more evident in the WSIZ areas where the water column is more stable, with shallow $z_{\text {mix }}$ and thus more light availability.

$N$ and $G$ were recalculated in carbon units. In WIS and MB1, $N(\mathrm{C})$ was equal to 28 and $21 \mathrm{mmol} \mathrm{m}^{-2} \mathrm{~d}^{-1}$, respectively; while $G\left({ }^{14} \mathrm{C}\right)$ was equal to 73 and $58 \mathrm{mmol} \mathrm{m}^{-2} \mathrm{~d}^{-1}$, respectively. For the POOZ, $N(\mathrm{C})$ was equal to $3 \mathrm{mmol} \mathrm{m}^{-2} \mathrm{~d}^{-1}$ for MB2 and WAI, while $G\left({ }^{14} \mathrm{C}\right)$ corresponded to $45 \mathrm{mmol} \mathrm{m}^{-2} \mathrm{~d}^{-1}$ in BT and $51 \mathrm{mg} \mathrm{m}^{-2} \mathrm{~d}^{-1}$ in MB2 and WAI (Table 2).

From the previous estimates, we calculated $f\left(\mathrm{O}_{2}\right)$ ratios as $f=N / G$ (Table 2). This fraction is similar to the $f$ ratio proposed by Eppley and Peterson (1979). The $f$ ratio was defined by the authors based on nitrate assimilation rates relative to the total assimilation of nitrogen. The $f$ ratio is an indicator of the ability of an ecosystem to retain or recycle organic matter by estimating the relative uptake of new versus total nitrogen (Eppley and Peterson, 1979). $f\left(\mathrm{O}_{2}\right)$ ratio is expected to be about half the $f$ ratio in terms of carbon since

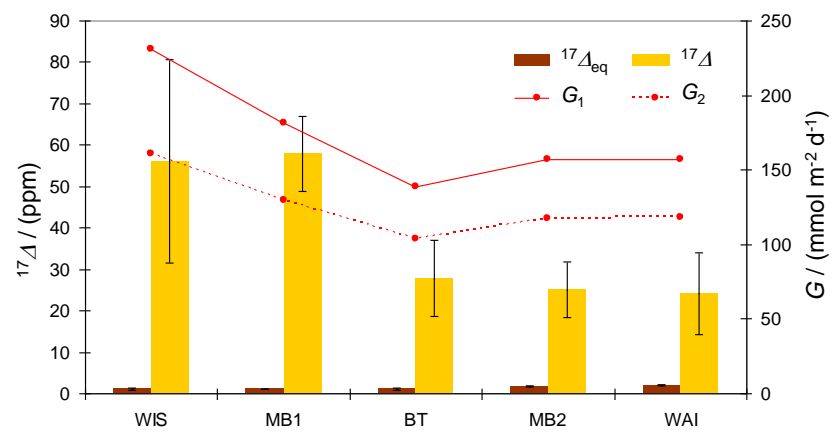

Fig. 9. Average ${ }^{17} \mathrm{O}$ excess $\left({ }^{17} \Delta\right)$ (yellow bars, left axis) and $G$ (red lines, right axis) in five areas in the Bellingshausen Sea. Brown bars represent the average ${ }^{17} \mathrm{O}$ excess at equilibrium with the atmosphere $\left({ }^{17} \Delta_{\text {eq }}\right.$ ), calculated from in situ temperatures (Luz and Barkan, 2009). Two different sets of parameters have been used to calculate $G_{1}$ and $G_{2}$ (see main text for details).

$\left.f\left(\mathrm{O}_{2}\right)=1.4 N(\mathrm{C}) / 2.7 G\left({ }^{14} \mathrm{C}\right)\right)$. For WIS the $f\left(\mathrm{O}_{2}\right)$ ratio was on average 0.19 and for MB1 of 0.16 . These values are notably higher than the ratio in the areas of the POOZ ( 0.02 for MB2 and 0.01 for WAI). In terms of carbon, the $f$ ratio for the areas in the WSIZ corresponded to 0.37 and 0.30 for the WIS and the MB1, respectively, while for the POOZ it was 0.04 and 0.02 for MB2 and WAI.

\section{Discussion}

\subsection{Influence of physical effects on $N$ and $G$ in the Bellingshausen Sea}

In the WSIZ, the presence of shallow mixed layers in a sheltered geographical location less exposed to the wind stress is related to the stable water column and may support biological growth after the peak of the growing season. In the POOZ, the combination of stronger winds and the lesser influence of freshwater by lateral advection from ice shelves may explain a less stable water column. Perissinotto et al. (1990) suggested that local physical processes in the WAP control the accumulation and dissipation of phytoplankton communities, being a more important process for marine production than in situ growth.

The effect of physical processes on the $N$ and $G$ estimated using the $\mathrm{O}_{2}$ budget approach in the Bellingshausen Sea cannot be neglected. In the POOZ, the ${ }^{17} \Delta$ values were on average two times smaller than in the WSIZ. In the BT an apparent net heterotrophy is observed from the $N$ values; however, the ${ }^{17} \mathrm{O}$ excess suggests the opposite with values well above the value in equilibrium with the atmospheric air (Fig. 9). This can be the result of the entrainment of waters below the mixed layer enriched in ${ }^{17} \Delta$.

Similar observations were drawn from Hendricks et al. (2004): the authors suggested that the entrainment of oxygen-undersaturated waters does not have a large impact 
on the upper ${ }^{17} \Delta$ because the $\mathrm{O}_{2}$ content in the entrained waters has already been low. The authors assumed that the ${ }^{17} \Delta$ of the added $\mathrm{O}_{2}$ is probably not far from the equilibrium value. Nevertheless, the results shown here suggest a possible incorporation of ${ }^{17} \Delta$ from below the mixed layer as a result of the mixed-layer deepening. Despite the $\Delta\left(\mathrm{O}_{2}\right)$ below the mixed layer during our sampling period being undersaturated due to respiration, the ${ }^{17} \Delta$ in dissolved oxygen is not affected by this process (Luz and Barkan, 2000, 2009).

High ${ }^{17} \Delta$ in waters below the mixed layer can result from diapycnal mixing or autogenic photosynthesis with limited loss of signal. During austral summer, the euphotic zone in the Southern Ocean can be deeper than the mixed layer. Huang et al. (2012) observed that the depth of the euphotic zone during summer was up to $37 \mathrm{~m}$ deeper than the mixed layer. Thus, photosynthetic $\mathrm{O}_{2}$ can accumulate underneath the shallow summer mixed layer due to the attenuation of vertical mixing. Evidence of this process in nutrient content has been observed previously in the WAP (Serebrennikova and Fanning, 2004) and in the MIZ of the Australian sector of the Southern Ocean where nutrients remain stored below the summer mixed layer from the preceding winter mixed layer (Ishii et al., 2002).

As the season progresses and the mixed layer gets deeper towards autumn, the ${ }^{17} \Delta$ excess of previously stored biological $\mathrm{O}_{2}$ entrains into upper waters. Luz and Barkan (2009) observed ${ }^{17} \Delta$ values above equilibrium with respect to air in samples from the Bermuda-Atlantic Time Series (BATS) station with the maximum production of ${ }^{17} \Delta$ in the thermocline. The authors suggested that the high ${ }^{17} \Delta$ must have been stored below the mixed layer before being delivered to waters above. Although in a different oceanic regime, similar processes might explain the high ${ }^{17} \mathrm{O}$ excess observed in the Bellingshausen Sea. However, due to the lack of ${ }^{17} \Delta$ data below the mixed layer in our study, this hypothesis cannot be corroborated. To our knowledge, no depth profiles of ${ }^{17} \Delta$ in the Southern Ocean have been published in the literature (Juranek and Quay, 2013).

Entrainment of waters below the mixed layer and vertical diffusion can bias the mixed-layer productivity determination not only in the Bellingshausen Sea. Hamme and Emerson (2006), at the Hawaii Ocean Time-series station ALOHA, used the $\mathrm{O}_{2}$ mass balance approach and concluded that vertical mixing below the mixed layer can lead to underestimating the $N$ by up to $70 \%$ at high mixing rates due to loss of $\mathrm{O}_{2}$ from the mixed layer. Nicholson et al. (2012) evaluated the contribution of entrainment (considered by the authors as upwelling, diapycnal mixing and mixed-layer depth changes) in the subtropical gyres contributed to deliverance of thermocline water with high ${ }^{17} \Delta$ content into the mixed layer. The authors concluded that neglecting the entrainment processes on productivity estimates can lead to overestimates by 60 to $80 \%$ of annually averaged primary production in the subtropical gyre using the $\mathrm{O}_{2}$ budget approach on a steady state.
Serebrennikova and Fanning (2004) observed during summer a high nutrient utilization away from the shore in Marguerite Bay. In this region we observed a decline of $N$ which might have occurred towards early autumn and after the consumption of nutrients. Meredith et al. (2010) described the circulation pattern inside Marguerite Bay from observations of a time series of $\delta^{18} \mathrm{O}\left(\mathrm{H}_{2} \mathrm{O}\right)$ measurements for seawater in order to trace the sea ice melt input to the ocean and the freshwater input from glacial and meteoric water in a site located in Marguerite Bay. The authors corroborated the heterogeneity of water properties in the bay with a higher influence of meteoric water during summer in northern MB (here MB2), compared with a contrasting oceanic influence due to the dominance of sea ice melt in the southern MB (here MB1). Our observations are in good agreement with Meredith et al. (2010) and Serebrennikova and Fanning.

\subsection{Role of upwelling and lateral advection in the Bellingshausen Sea}

Strength and direction of the wind play an important role in coastal upwelling, sea ice distributions and the resulting biological communities and distribution of $\mathrm{O}_{2}$. As a consequence of the predominant winds during our study, winddriven coastal upwelling was most likely negligible during the sampling period. Smith et al. (2008) suggested that the dynamics in coastal waters of Marguerite Bay might have a strong influence on the marine productivity of this region by upward transport of CDW to the shelf from late summer to autumn. High levels of pigment biomass were encountered during the seasonal transition (Smith et al., 2008). This period is coincident with the sampling dates of the present study. Wallace et al. (2008) suggested that upwelling is intermittent in Marguerite Bay. From observations collected during the same time as cruise JR165 by a mooring located in the entrance of Marguerite Bay, the authors concluded that upwelling was only evident in March 2007, but not during the previous two months.

The strength and periodicity of upwelling at the continental shelf of the Bellingshausen Sea is unclear. Studies from moorings or tracers with high spatial resolution, such as oxygen, can help to elucidate $\mathrm{O}_{2}$ budget (and $N$ ) of the Bellingshausen Sea.

Lateral advection is another important process that may affect the marine productivity in upper waters of the Bellingshausen Sea. Temperature inversions close to Charcot Island suggest lateral contribution of melt water from the coast into the mixed layer, which cannot be quantified based on our measurements.

\subsection{Effect of ice on air-sea gas exchange}

Sea ice might limit the air-sea gas exchange. Only sparse laboratory and field measurements have been performed so far in order to understand how sea ice affects the gas flux 
between the ocean and the atmosphere (Fanning and Torres, 1991; Loose et al., 2009; Loose and Schlosser, 2011). Results of these experiments show an average moderate gas transfer reduction of about $25 \%$ in the presence of up to $70 \%$ ice cover and surface freshwater lenses with salinities between 10 and 33 (Fanning and Torres, 1991). It is unclear how the reduction of gas exchange scales with air-sea exchange (Loose and Schlosser, 2011) and there is currently no parameterization available for $k$ in regions affected by sea ice. During our cruise the WSIZ was mainly characterized by open water with the presence of sparse ice floes - a typical condition towards the end of the melt season in this region. We encountered complete fast ice cover close to Charcot Island; however, the underway system onboard was shut down and no sampling for $\mathrm{O}_{2} / \mathrm{Ar}$ and $\mathrm{O}_{2}$ was done. The results presented here were taken at the end of the productive season, when sea ice was just starting to increase again. Since our gas exchange flux calculations were weighted over the 60 days prior to sampling, when sea ice cover would have been even less than we observed during the cruise, we do not consider a correction of air-sea exchange for sea ice to be appropriate.

\subsection{Comparison with previous marine production estimates}

To our knowledge the only published in vitro net community production measurements in the Bellingshausen Sea are those of Boyd et al. (1995). The authors derived depthintegrated $N$ from dissolved oxygen changes in bottle incubations during November/December in 1993 at stations along $85^{\circ} \mathrm{W}$ and between $70^{\circ} \mathrm{S}$ and $67.5^{\circ} \mathrm{S}$. Sampling season (late spring to beginning of summer compared to our sampling during the period of the end of summer to beginning of autumn) and geographical location (nearly $100 \mathrm{~km}$ north of our northernmost stations) differ from our study. Boyd et al. (1995) observed a retreat of the ice margin, whereas during our cruise the sea ice was advancing. We therefore limit the comparison with our results to the region that remained ice free during our sampling period (i.e., west of Adelaide Island, between $67^{\circ}$ and $66^{\circ} \mathrm{S}$ and $70^{\circ}$ to $74^{\circ} \mathrm{W}$ ). Boyd et al. (1995) reported a high chlorophyll feature at $67^{\circ} 30^{\prime} \mathrm{S}$ that was associated with a hydrographic front and not the retreating ice edge. This area with high rates of plankton metabolism was characterized by deep mixed-layer depths (up to $70 \mathrm{~m}$ ) and a shallow euphotic layer $(30 \mathrm{~m})$ in station $\mathrm{K}$, while a similar mixed-layer depth and euphotic zone were observed in station $\mathrm{J}(>50 \mathrm{~m})$. From the data in their Table 3 , we derived mixed-layer $N$ values of $(181 \pm 36)$ mmol m${ }^{-2} \mathrm{~d}^{-1}$ and $(46 \pm 22) \mathrm{mmol} \mathrm{m}^{-2} \mathrm{~d}^{-1}$ (station K). Our $N$ values of $(4 \pm 20) \mathrm{mmol} \mathrm{m}^{-2} \mathrm{~d}^{-1}$ in the WAI area are considerably lower than the values from Boyd et al., and this is possibly due to the latter being obtained towards the peak of the growing season in contrast to our case. Despite the difference of our values, the biological oxygen flux in the WAI region of $(-20 \pm 12) \mathrm{mmol} \mathrm{m}^{-2} \mathrm{~d}^{-1}$ on its own would not have shown autotrophy without the correction we made due to entrainment.

A comparison of net community production estimates based on other methods, such as ${ }^{14} \mathrm{C}$ incubations, must be interpreted with caution (Juranek and Quay, 2013; Robinson et al., 2009). Our measurements represent net community $\mathrm{O}_{2}$ production, integrated over the mixed layer and the $\mathrm{O}_{2}$ gas exchange time. In contrast, productivity derived from incubations approximates primary productivity integrated to the depth of the euphotic zone. Furthermore, net productivity estimated from satellite data represents only the top few centimeters of the water column and is integrated by numerical algorithms to the euphotic zone.

Vernet et al. (2008) estimated an integrated euphotic zone primary production for January of $745 \mathrm{mg} \mathrm{m}^{-2} \mathrm{~d}^{-1}$ $\left(62 \mathrm{mmol} \mathrm{m}^{-2} \mathrm{~d}^{-1}\right)$ by averaging $12 \mathrm{yr}$ of ${ }^{14} \mathrm{C}$ bottle incubations in the sea ice zone west of the Antarctic Peninsula. The data showed a maximum of $1788 \mathrm{mg} \mathrm{m}^{-2} \mathrm{~d}^{-1}$ $\left(149 \mathrm{mmol} \mathrm{m}^{-2} \mathrm{~d}^{-1}\right)$ in 2006 and a minimum of $248 \mathrm{mg} \mathrm{m}^{-2} \mathrm{~d}^{-1}\left(21 \mathrm{mmol} \mathrm{m}^{-2} \mathrm{~d}^{-1}\right)$ in 1999. An onshoreoffshore gradient of the estimated rates of net primary production was observed, particularly in the Marguerite Bay region, with the highest values at the mouth of the bay. The $N$ values presented here for the WSIZ (mean of $24 \mathrm{mmol} \mathrm{m}^{-2} \mathrm{~d}^{-1}$ ) are closer to the minimum value; this is probably due to our measurements being performed in March to April, well after the peak of the growing season (January).

For the shelf areas of the Bellingshausen and Amundsen seas, Arrigo et al. (2008) estimated the highest mean daily primary production over a $9 \mathrm{yr}$ period (1997 to 2006) as $316 \mathrm{mg} \mathrm{m}^{-2} \mathrm{~d}^{-1}\left(158 \mathrm{mmol} \mathrm{m}^{-2} \mathrm{~d}^{-1}\right)$. Their results are based on remotely sensed ocean color, sea surface temperature and sea ice concentration data. Their estimates are the highest for this area compared to the pelagic and MIZ zones and the results presented here are in close agreement.

High primary production (PP) in inshore regions of the WAP, compared to the ones beyond the shelf break have also been observed by others (i.e., Smith et al., 1998; Garibotti et al., 2003; Serebrennikova and Fanning, 2004; Mengesha et al., 2008). Agustí and Duarte (2005) confirmed that about $2 \mathrm{mmol} \mathrm{m}^{-3} \mathrm{~d}^{-1}$ is a threshold for gross primary production (GPP) to delineate the presence of net heterotrophic communities (i.e., where $R>$ GPP) in the $\mathrm{SO}$ from $\mathrm{O}_{2}$ measurements in a mesocosm experiment. For an average mixed-layer depth of $50 \mathrm{~m}$, this value is equivalent to 100 mmol m $\mathrm{m}^{-2} \mathrm{~d}^{-1}$, which is in close agreement to our $G$ estimates in the POOZ $\left(110 \mathrm{mmol} \mathrm{m}^{-2} \mathrm{~d}^{-1}\right.$ ) (Agustí and Duarte, 2005) Due to differences in the methods to estimate marine productivity so far applied in the WAP, the comparison to previous values of $N$ and $G$ in the Bellingshausen Sea is limited to results from the same approach used here. Hendricks et al. (2004) published results of $N$ and $G$ for samples collected in the Bellingshausen Sea during March in 2000. The authors show a decrease in the $G$ values towards the south 


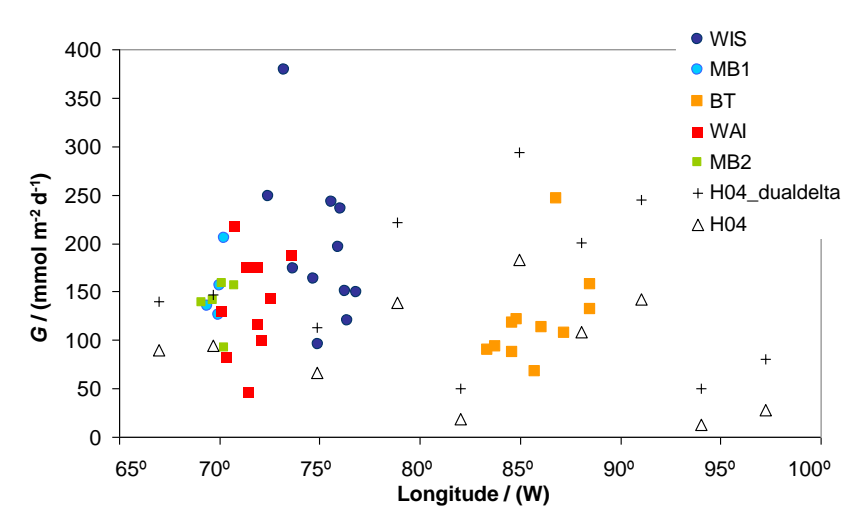

Fig. 10. Longitudinal distribution of $G$ (average of $G_{1}$ and $G_{2}$ ). Comparison to results obtained by Hendricks et al. (2004) (H04) during March 2000 using ${ }^{17} \Delta$ and recalculated values (H04_dualdelta) using ${ }^{17} \delta$ and ${ }^{18} \delta$.

$\left(70^{\circ} \mathrm{S}\right)$ and west $\left(98^{\circ} \mathrm{W}\right)$. The average $G$ values shown by Hendricks et al. are about $25 \mathrm{mmol} \mathrm{m}^{-2} \mathrm{~d}^{-1}, 5$ times smaller than the values presented here. This difference is due to the ${ }^{17} \Delta_{\text {eq }}$ value used for $G$ calculation. The authors considered the standard value of $+16 \mathrm{ppm}$ (following Luz and Barkan, 2000), while here we estimated the ${ }^{17} \Delta_{\text {eq }}$ independently for each sample, depending on their corresponding sea surface temperature.

For better comparison to this work, we have recalculated Hendricks' values. $G$ was obtained, as in this work, from the dual-delta method following Eq. (8), along with the ${ }^{18} \delta_{\text {eq }}$ parameterization by Benson et al. (1979) and ${ }^{17} \Delta_{\text {eq }}$ from Luz and Barkan (2009). In their supplementary material presented by Reuer et al. (2007), the ${ }^{17} \delta$ values were not reported, but were calculated from the given $\Delta^{17}$ and ${ }^{18} \delta$ values. The concentration of oxygen was also not provided in the supplementary material; therefore, we calculated them from the $\Delta\left(\mathrm{O}_{2} / \mathrm{Ar}\right)$ and $c_{\mathrm{sat}}\left(\mathrm{O}_{2}\right)$ provided. For this we assumed that $c(\mathrm{Ar})$ equals $c_{\mathrm{eq}}(\mathrm{Ar})$; thus,

$c\left(\mathrm{O}_{2}\right)=c_{\mathrm{eq}}\left(\mathrm{O}_{2}\right) \times\left(\Delta\left(\mathrm{O}_{2} / \mathrm{Ar}\right)+1\right)$.

The comparison of $G$ between our results with the ones by Hendricks et al. (2004) following the traditional calculation based on ${ }^{17} \mathrm{O}$ excess and the recalculated $G$ values from the dual-delta method, are depicted in Fig. 10. The recalculated values for gross oxygen production from Hendricks et al. are from only 11 discrete points distributed in the POOZ of the Bellingshausen Sea. Our results from discrete points distributed in the same zone (average of $\left.(156 \pm 65) \mathrm{mmol} \mathrm{m}^{-2} \mathrm{~d}^{-1}\right)$, are in good agreement with the re calculated $G$ values (average $154 \pm 84$ ) $\mathrm{mmol} \mathrm{m}^{-2} \mathrm{~d}^{-1}$ ). In all cases, the $N$ values from Hendricks et al. (2004) were negative (average of $-25 \mathrm{mmol} \mathrm{m}^{-2} \mathrm{~d}^{-1}$ ), which is in close agreement with our $F_{\text {bio }}$ values (before correction by physical effects) with an average of $-16.8 \mathrm{mmol} \mathrm{m}^{-2} \mathrm{~d}^{-1}$ for the POOZ.
From the observations made by Huang et al. (2012), it was not possible to recalculate $G$ using the dual-delta method due to the lack of ${ }^{17} \delta,{ }^{18} \delta$ and $c\left(\mathrm{O}_{2}\right)$ data in the supplementary material. Despite the different approach for calculation, and although the area of study by Huang et al. (2012) was located north of our area of study and mainly in the POOZ, the ${ }^{17} \Delta$ values for the only overlapping section to our area of study and where data are available (i.e., in Huang et al. (2012) study transect line 200 consisting of 11 discrete data points off Marguerite Bay) are in close agreement with our results. The average ${ }^{17} \Delta$ in Huang et al. (2012) is comparable $((27 \pm 22) \mathrm{ppm})$ to the mean ${ }^{17} \Delta$ values obtained in this study for the WAI area $((24 \pm 10) \mathrm{ppm})$. In contrast to the results presented here, Huang et al. (2012) used ${ }^{17} \Delta$ to estimate $G$; thus, it is not possible to compare directly their results with our $G$ estimates. In order to make an approximate comparison to $G$ estimates, here we increased the $G$ values from Huang et al. (2012) by $30 \%$, based on the observed difference from ${ }^{17} \Delta G$ and dual-delta $G$ values reported previously (Kaiser and Abe, 2012). Thus, the $G$ values from Huang et al. (2012) following the dual-delta approach would correspond approximately to $(150 \pm 90) \mathrm{mmol} \mathrm{m}^{-2} \mathrm{~d}^{-1}$, while for the present study we obtained an average of $(142 \pm 54) \mathrm{mmol} \mathrm{m}^{-2} \mathrm{~d}^{-1}$ for the WAI area. In contrast, Huang reported that $\Delta\left(\mathrm{O}_{2} / \mathrm{Ar}\right)$ remained low but positive $((1.0 \pm 0.8) \%)$, whereas we observed negative $\Delta\left(\mathrm{O}_{2} / \mathrm{Ar}\right)$ in the WAI area $((-2.4 \pm 0.9) \%)$. This difference is probably due to the sampling time between both studies. While Huang's study occurred during the peak of the growing season, the present study occurred towards the beginning of autumn.

Several estimates for $f\left(\mathrm{O}_{2}\right)$ ratios have been published and are compiled recently in Juranek and Quay (2013). Hendricks et al. in 2005 reported values for the equatorial Pacific with a mean of 0.06. Reuer et al. (2007) obtained an average value for $f\left(\mathrm{O}_{2}\right)$ ratios equal to 0.13 in some regions of the Southern Ocean during summer. Luz and Barkan (2009) obtained values of 0.08 to 0.21 from samples collected at the BATS site in the Atlantic Ocean during May to October, 2000. Recently, Huang et al. (2012), reported $f\left(\mathrm{O}_{2}\right)$ values for the WAP from -0.04 to 0.43 , while Hamme et al. (2012) presented mean values between 0.08 and 0.12 in the Pacific sector of the Southern Ocean. Our results, with values from 0.02 at the POOZ and 0.2 at the WSIZ, are in agreement with the previous observations in the Southern Ocean and in other oceanic regions. This agreement is expected due to the large range of values reported so far in different regions of the global ocean (Hamme et al., 2012)

\section{Conclusions and outlook}

We presented high spatiotemporal resolution net community production from oxygen measurements in the Bellingshausen Sea. The distribution of $N$ was found to be related 
to the location of the marginal ice zone and water column stability. Diapycnal flux by diffusivity $\left(F_{\mathrm{v}}\right)$ is less important than $\left(F_{\mathrm{e}}\right)$, particularly in the POOZ. Net heterotrophy was restricted to offshore areas during the time frame that the mixed-layer $N$ estimates represent in this work.

The results presented here are estimates of mixed-layer productivity as a snapshot for the seasonal transition from summer to autumn in 2007 integrated over the residence time of oxygen in the mixed layer. Despite the high uncertainty in the $N$ estimates, the method used here was successful at identifying the high heterogeneity in marine productivity in the Bellingshausen Sea. Our results also highlight the importance of correcting for physical processes in regions where they have a large influence on the surface $\mathrm{O}_{2}$ budget. Other processes, such as upwelling and lateral advection, should also be considered in the $\mathrm{O}_{2}$ mass balance.

A predicted rise in temperatures and ice melting, as well as a delay of sea ice formation by strengthening of winds, can lead to an increase of the primary productivity along the coast in the Bellingshausen Sea. Lengthening the growing season towards autumn thanks to increased light availability may also extend the growing season.

\section{Appendix A}

In this Appendix we derive Eq. (6) used to estimate the influence of vertical mixing during entrainment of thermocline waters $\left(F_{\mathrm{e}}\right)$ when the mixed layer deepens.

Emerson et al. (2008) represented the entrainment flux due to a change of mixed-layer depth over the time $\left(\Delta z_{\text {mix }} / \Delta t\right)$ as

$F_{\mathrm{e}}=\left(c_{\mathrm{T}}-c_{0}\right) \frac{\Delta z_{\mathrm{mix}}}{\Delta t}$,

where $c_{\mathrm{T}}$ represents the concentration in the thermocline below the mixed layer and $c$ the concentration in the mixed layer before the deepening event.

However, usually the concentration in the thermocline is not uniform. We therefore derive an equation that takes the concentration gradient below the bottom of the mixed layer into account. Since we are interested in $\mathrm{O}_{2}$, the relevant concentration gradient is the oxycline.

A simple mass balance describing the change of the mixed-layer $\mathrm{O}_{2}$ inventory during mixed-layer deepening can be written as

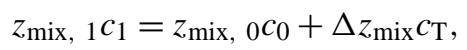

where $\Delta z_{\text {mix }}$ is the change in mixed-layer depth $\left(\Delta z_{\text {mix }}=z_{\text {mix }, 1}-z_{\text {mix }, 0}\right)$, and $c_{\mathrm{T}}$ in this case represents the average $\mathrm{O}_{2}$ concentration of the entrained water from the oxycline.
Expressing the change in $\mathrm{O}_{2}$ concentration as $\Delta c=c_{1}-c_{0}$, Eq. (A2) can be written as

$z_{\text {mix }, 1} \Delta c=\Delta z_{\text {mix }}\left(c_{\mathrm{T}}-c_{0}\right)$.

Assuming a concentration gradient $\partial c\left(\mathrm{O}_{2}\right) /\left.\partial z\right|_{\text {oxy }}$ in the oxycline, the average concentration of the entrained water is

$$
\begin{aligned}
c_{\mathrm{T}} & =\frac{1}{2}\left(c_{0}+c_{0}+\left.\Delta z_{\text {mix }} \frac{\partial c\left(\mathrm{O}_{2}\right)}{\partial z}\right|_{\text {oxy }}\right) \\
& =c_{0}+\left.\frac{1}{2} \Delta z_{\text {mix }} \frac{\partial c\left(\mathrm{O}_{2}\right)}{\partial z}\right|_{\text {oxy }} .
\end{aligned}
$$

Thus,

$z_{\text {mix }, 1} \Delta c=\left.\frac{1}{2}\left(\Delta z_{\text {mix }}\right)^{2} \frac{\partial c\left(\mathrm{O}_{2}\right)}{\partial z}\right|_{\text {oxy }}$,

and the entrainment flux is given by

$F_{\mathrm{e}}=z_{\text {miz }, 1} \frac{\Delta c}{\Delta t}=\left.\frac{1}{2} \frac{\left(\Delta z_{\text {mix }}\right)^{2}}{\Delta t} \frac{\partial c\left(\mathrm{O}_{2}\right)}{\partial z}\right|_{\text {oxy }}$.

A decrease of $\mathrm{O}_{2}$ with depth leads to a decrease of $c$ in the mixed layer during mixing, corresponding to a negative sign for $F_{\mathrm{e}}$. The approach relies on the assumption that the $\mathrm{O}_{2}$ gradient in the oxycline at the time of sampling is the same as before the mixing event.

\section{Supplementary material related to this article is available online at: $\mathrm{http}: / / \mathrm{www} . b i o g e o s c i e n c e s . n e t / 10 /$ 2273/2013/bg-10-2273-2013-supplement.pdf.}

Acknowledgements. The British Antarctic Survey (BAS) and the Natural Environment Research Council supported this project through grant CGS8/29. K. C. M. thanks the National Council for Science and Technology (CONACyT), Mexico, for her PhD scholarship at the University of East Anglia. J. K. was also supported by a Royal Society Research Merit Award (WM052632). Special thanks to Adrian Jenkins (leader of ACES-FOCAS project) as well as to the participants and crew of cruise JR165. The authors would like to thank Michael Bender for allowing the analysis of the isotope samples at his lab in Princeton University. This work benefited from support provided to Michael Bender by the Office of Polar Programs of NSF and NASA.

The oxygen isotope data from this work can be found in the accompanying supplementary material. The hydrographic CTD data can be accessed by contacting co-author Deborah R. Shoosmith (drsho@bas.ac.uk).

Edited by: K. Suzuki 


\section{References}

Agustí, S. and Duarte, C. M.: Threshold of gross primary production for planktonic metabolic balance in the Southern Ocean: An experimental test, Limnol. Oceanogr., 50, 1334-1339, doi:10.4319/lo.2005.50.4.1334, 2005.

Arrigo, K. R., van Dijken, G. L., and Bushinsky, S.: Primary production in the Southern Ocean, 1997-2006, J. Geophys. Res., 113, C08004, doi:10.1029/2007JC004551, 2008.

Barkan, E. and Luz, B.: The relationships among the three stable isotopes of oxygen in air, seawater and marine photosynthesis, Rapid Commun. Mass. Sp., 25, 2367-2369, doi:10.1002/rcm.5125, 2011.

Bender, M., Orchardo, J., Dickson, M.-L., Barber, R., and Lindley, S.: In vitro $\mathrm{O}_{2}$ fluxes compared with ${ }^{14} \mathrm{C}$ production and other rate terms during the JGOFS Equatorial Pacific experiment, Deep-Sea Res. I, 46, 637-654, doi:10.1016/09670645(95)00068-2, 1999.

Benson, B. B., Krause, D., and Peterson, M. A.: The solubility and isotopic fractionation of gases in dilute aqueous solution. I. Oxygen, J. Solution Chem., 8, 9, 655-690, doi:10.1007/BF01033696, 1979.

Boyd, P. W., Robinson, C., Savidge, G., and Williams, P. J. 1.: Water column and sea-ice primary production during Austral spring in the Bellingshausen Sea, Deep-Sea Res. II, 42, 1177-1200, doi:10.1016/0967-0645(95)00070-7, 1995.

Boyd, P. W., Watson, A. J., Law, C. S., Abraham, E. R., Trull, T. W., Murdoch, R., Bakker, D. C. E., Bowie, A. R., Buesseler, K. O., Chang, H., Charette, M., Croot, P., Downing, K., Frew, R., Gall, M., Hadfield, M., Hall, J., Harvey, M., Jameson, G., LaRoche, J., Liddicoat, M. I., Ling, R., Maldonado, M. T., McKay, R. M., Nodder, S., Pickmere, S., Pridmore, R., Rintoul, S. R., Safi, K., Sutton, P., Strzepek, R., Tanneberger, K., Turner, S., Waite, A., and Zeldis, J.: A mesoscale phytoplankton bloom in the polar Southern Ocean stimulated by iron fertilization, Nature, 407, 695-702, doi:10.1038/35037500, 2000.

Cassar, N., Bender, M. L., Barnett, B., Fan, S., Moxim, W. J., Levy II, H., and Tilbrook, B.: The Southern Ocean biological response to aeolian iron deposition, Science, 317, 1067-1070, doi:10.1126/science.1144602, 2007.

Cassar, N., DiFiore, P. J., Barnett, B. A., Bender, M. L., Bowie, A. R., Tilbrook, B., Petrou, K., Westwood, K. J., Wright, S. W., and Lefevre, D.: The influence of iron and light on net community production in the Subantarctic and Polar Frontal Zones, Biogeosciences, 8, 227-237, doi:10.5194/bg-8-227-2011, 2011.

Castro-Morales, K. and Kaiser, J.: Using dissolved oxygen concentrations to determine mixed layer depths in the Bellingshausen Sea, Ocean Sci., 8, 1-10, doi:10.5194/os-8-1-2012, 2012.

Cook, A. J., Fox, A. G., Vaughan, D. G., and Ferrigno, J. G.: Retreating Glacier Fronts on the Antarctic Peninsula over the Past Half-Century, Science, 308, 541-544, doi:10.1126/science.1104235, 2005.

Craig, H. and Hayward, T.: Oxygen supersaturation in the ocean: Biological versus physical contributions, Science, 235, 199-202, doi:10.1126/science.235.4785.199, 1987.

de Boyer Montégut, C., Madec, G., Fisher, A. S., Lazar, A., and Iudicone, D.: Mixed layer depth over the global ocean: an examination of profile data and profile-based climatology, J. Geophys. Res., 109, C12003, doi:10.1029/2004JC002378, 2004.
Dickson, A. G.: Determination of dissolved oxygen in seawater by Winkler titration, in: WOCE Operations Manual, Volume 3: The Observational Programme, Section 3.1: WOCE Hydrographic Programme. Part 3.1.3: WHP Operations and Methods, edited by: World Ocean Circulation Experiment, Woods Hole, Massachussetts, USA, 1-13, 1996.

Ducklow, H. W., Baker, K. S., Martinson, D. G., Quetin, L. B., Ross, R. M., Smith, R. C., Stammerjohn, S., Vernet, M., and Fraser, W.: Marine pelagic ecosystem: the West Antarctic Peninsula, Philos. T. Roy. Soc., 362, 67-94, doi:10.1098/rstb.2006.1955, 2007.

Eisenstadt, D., Barkan, E., Luz, B., and Kaplan, A.: Enrichment of oxygen heavy isotopes during photosynthesis in phytoplankton, Photosynth. Res., 103, 97-103, doi:10.1007/s11120-009-9518-z, 2010.

Emerson, S.: Seasonal oxygen cycles and biological new production in surface waters of the subarctic Pacific Ocean, J. Geophys. Res., 92, 6535-6544, doi:10.1029/JC092iC06p06535, 1987.

Emerson, S., Quay, P., Stump, C., Wilbur, D., and Schudlich, R.: Chemical tracers of productivity and respiration in the subtropical Pacific Ocean, J. Geophys. Res., 100, 15873-15887, doi:10.1029/95JC01333, 1995.

Emerson, S., Stump, C., and Nicholson, D.: Net biological oxygen production in the ocean: Remote in situ measurements of $\mathrm{O}_{2}$ and $\mathrm{N}_{2}$ in surface waters, Global Biogeochem. Cy., 22, GB3023, doi:10.1016/j.dsr.2010.06.001, 2008.

Eppley, R. W. and Peterson, B. J.: Particulate organic matter flux and planktonic new production in the deep ocean, Nature, 282, 677-680, doi:10.1038/282677a0, 1979.

Fanning, K. A. and Torres, L. M.: ${ }^{222} \mathrm{Rn}$ and ${ }^{226} \mathrm{Ra}$ : indicators of sea-ice effects on air-sea gas exchange, Polar Res., 10, 51-58, doi:10.1111/j.1751-8369.1991.tb00634.x, 1991.

Garcia, H. E. and Gordon, L. I.: Oxygen solubility in seawater: better fitting equations, Limnol. Oceanogr., 37, 1307-1312, doi:10.4319/lo.1992.37.6.1307, 1992.

Garcia, H. E. and Gordon, L. I.: Erratum: Oxygen solubility in seawater: Better fitting equations, Limnol. Oceanogr., 38, p. 656, 1993.

Garibotti, I. A., Vernet, M., Ferrario, M. E., Smith, R. C., Ross, R. M., and Quetin, L. B.: Phytoplankton spatial distribution patterns along the western Antarctic Peninsula (Southern Ocean), Mar. Ecol.-Prog. Ser., 261, 21-39, doi:10.3354/meps261021, 2003.

Garibotti, I. A., Vernet, M., and Ferrario, M. E.: Annually recurrent phytoplanktonic assemblages during summer in the seasonal ice zone west of the Antarctic Peninsula (Southern Ocean), Deep-Sea Res. I, 52, 1823-1841, doi:10.1016/j.dsr.2005.05.003, 2005a.

Garibotti, I. A., Vernet, M., Smith, R. C., and Ferrario, M. E.: Interannual variability in the distribution of the phytoplankton standing stock across the seasonal sea-ice zone west of the Antarctic Peninsula, J. Plankton Res., 27, 825-843, doi:10.1093/plankt/fbi056, 2005b.

Graham, A. G. C., Nitsche, F. O., and Larter, R. D.: An improved bathymetry compilation for the Bellingshausen Sea, Antarctica, to inform ice-sheet and ocean models, The Cryosphere, 5, 95106, doi:10.5194/tc-5-95-2011, 2011.

Guéguen, C. and Tortell, P. D.: High-resolution measurements of Southern Ocean $\mathrm{CO}_{2}$ and $\mathrm{O}_{2} / \mathrm{Ar}$ by membrane inlet mass spectrometry, Mar. Chem., 108, 184-194, doi:10.1016/j.marchem.2007.11.007, 2008. 
Hamme, R. C. and Emerson, S. R.: The solubility of neon, nitrogen and argon in distilled water and seawater, Deep-Sea Res. I, 51, 1517-1528, doi:10.1016/j.dsr.2004.06.009, 2004.

Hamme, R. C. and Emerson, S. R.: Constraining bubble dynamics and mixing with dissolved gases: Implications for productivity measurements by oxygen mass balance, J. Mar. Res., 64, 73-95, doi:10.1357/002224006776412322, 2006.

Hamme, R. C. and Severinghaus, J. P.: Trace gas disequilibria during deep-water formation, Deep-Sea Res. I, 54, 939-950, doi:10.1016/j.dsr.2007.03.008, 2007.

Hamme, R. C., Cassar, N., Lance, V. P., Vaillancourt, R. D., Bender, M. L., Strutton, P. G., Moore, T. S., DeGrandpre, M. D., Sabine, C. L., Ho, D. T., and Hargreaves, B. R.: Dissolved $\mathrm{O}_{2} / \mathrm{Ar}$ and other methods reveal rapid changes in productivity during a Lagrangian experiment in the Southern Ocean, J. Geophys. Res., 117, C00F12, doi:10.1029/2011JC007046, 2012.

Hendricks, M. B., Bender, M. L., and Barnett, B. A.: Net and gross $\mathrm{O}_{2}$ production in the Southern Ocean from measurements of biological $\mathrm{O}_{2}$ saturation and its triple isotope composition, DeepSea Res. I, 51, 1541-1561, doi:10.1016/j.dsr.2004.06.006, 2004.

Hendricks, M. B., Bender, M. L., Barnett, B., Strutton, P. G., and Chavez, F. P.: Triple oxygen isotope composition of dissolved $\mathrm{O}_{2}$ in the equatorial Pacific: $A$ tracer of mixing, production, and respiration, J. Geophys. Res., 110, C12021, doi:10.1029/2004JC002735, 2005.

Hiraike, Y. and Ikeda, M.: Descending surface water at the Antarctic Marginal Ice Zone and its contribution to Intermediate Water: an ice-ocean model, J. Oceanogr., 65, 587-603, doi:10.1007/s10872-009-0050-8, 2009.

Hofmann, E. E. and Klinck, J. M.: Thermohaline variability of the waters overlying the west Antarctic Peninsula continental shelf, Foundations for ecosystem research in the western Antarctic Peninsula region, edited by: Ross, R., Hofmann, E. E., and Quentin, E., American Geophysical Union, Washington, DC, 6180, 1998.

Holland, P. R., Jenkins, A., and Holland, D. M.: Ice and ocean processes in the Bellingshausen Sea, Antarctica, J. Geophys. Res., 115, C05020, doi:10.1029/2008JC005219, 2010.

Holm-Hansen, O., Kahru, M., and Hewes, C. D.: Deep chlorophyll a maxima (DCMs) in pelagic Antarctic waters, II. Relation to bathymetric reatures and dissolved iron concentrations, Mar. Ecol.-Prog. Ser., 297, 71-81, doi:10.3354/meps297071, 2005.

Hopkinson, B., Greg Mitchell, B., Reynolds, R. A., Wang, H., Selph, K. E., Measures, C. I., Hewes, C. D., Holm-Hansen, O., and Barbeau, K. A.: Iron limitation across chlorphyll gradients in the southern Drake Passage: Phytoplankton responses to iron addition and photosynthetic indicators of iron stress, Limnol. Oceanogr., 55, 2540-2554, doi:10.4319/lo.2007.52.6.2540, 2007.

Howard, S. L., Hyatt, J., and Padman, L.: Mixing in the pycnocline over the western Antarctic Peninsula shelf during Southern Ocean GLOBEC, Deep-Sea Res. II, 51, 1965-1979, doi:10.1016/j.dsr2.2004.08.002, 2004.

Huang, K., Ducklow, H. W., Vernet, M., Cassar, N., and Bender, M. L.: Export production and its regulating factors in the West Antarctica Peninsula region of the Southern Ocean, Global Biogeochem. Cy., 26, GB2005, doi:10.1029/2010GB004028, 2012.

Ishii, M., Inoue, H. Y., and Matsueda, H.: Net community production in the marginal ice zone and its importance for the vari- ability of the oceanic $p \mathrm{CO}_{2}$ in the southern Ocean south of Australia, Deep-Sea Res. II, 49, 1691-1706, doi:10.1016/S09670645(02)00007-3, 2002.

Jacobs, S. S., Hellmer, H. H., and Jenkins, A.: Antarctic ice sheet melting in the Southeast Pacific, Geophys. Res. Lett., 23, 957960, doi:10.1029/96GL00723, 1996.

Jenkins, A. and Jacobs, S. S.: Circulation and melting beneath George VI Ice Shelf, Antarctica, J. Geophys. Res., 113, C04013, doi:10.1029/2007JC004449, 2008.

Johnson, H. K.: Simple expressions for correcting wind speed data for elevation, Coast. Eng., 36, 263-269, doi:10.1016/S03783839(99)00016-2, 1999.

Juranek, L. W. and Quay, P. D.: Using triple oxygen isotopes of dissolved oxygen to evaluate global marine productivity, Annual Review of Marine Science, Reviews in Advance, 5, 10.11-10.22, doi:10.1146/annurev-marine-121211-172430, 2013.

Kaiser, J.: Technical note: Consistent calculation of aquatic gross production from oxygen triple isotope measurements, Biogeosciences, 8, 1793-1811, doi:10.5194/bg-8-1793-2011, 2011.

Kaiser, J. and Abe, O.: Reply to Nicholson's comment on "Consistent calculation of aquatic gross production from oxygen triple isotope measurements" by Kaiser (2011), Biogeosciences, 9, 2921-2933, doi:10.5194/bg-9-2921-2012, 2012.

Kaiser, J., Reuer, M. K., Barnett, B., and Bender, M. L.: Marine productivity estimates from continuous oxygen/argon ratio measurements by shipboard membrane inlet mass spectrometry, Geophys. Res. Lett., 32, L19605, doi:10.1029/2005GL023459, 2005.

Kana, T. M., Darkangelo, C., Hunt, M. D., Oldham, J. B., Bennett, G. E., and Cornwell, J. C.: Membrane inlet mass spectrometer for rapid high-precision determination of $\mathrm{N}_{2}, \mathrm{O}_{2}$, and $\mathrm{Ar}$ in environmental water samples, Anal. Chem., 66, 23, 4166-4170, doi:10.1021/ac00095a009, 1994.

Keeling, R. F. and Garcia, H. E.: The change in oceanic $\mathrm{O}_{2}$ inventory associated with recent global warming, Proc. Natl. Acad. Sci. USA, 99, 7848-7853, doi:10.1073/pnas.122154899, 2002.

Knox, M., Quay, P. D., and Wilbur, D.: Kinetic isotopic fractionation during air-water gas transfer of $\mathrm{O}_{2}, \mathrm{~N}_{2}, \mathrm{CH}_{4}$, and $\mathrm{H}_{2}$, J. Geophys. Res., 97, 20335-20343, doi:10.1029/92JC00949, 1992.

Law, C. S., Abraham, E. R., Watson, A. J., and Liddicoat, M. I.: Vertical eddy diffusion and nutrient supply to the surface mixed layer of the Antarctic Circumpolar Current, J. Geophys. Res., 108, 3272, doi:10.1029/2002JC001604, 2003.

Laws, E. A.: Photosynthetic quotients, new production and net community production in the open ocean, Deep-Sea Res., 38, 143167, doi:10.1016/0198-0149(91)90059-O, 1991.

Le Quéré, C., Rödenbeck, C., Buitenhuis, E. T., Conway, T. J., Langenfelds, R., Gomez, A., Labuschagne, C., Ramonet, M., Nakazawa, T., Metzl, N., Gillet, N., and Heimann, M.: Saturation of the Southern Ocean $\mathrm{CO}_{2}$ sink due to recent climate change., Science, 316, 1735-1738, doi:10.1126/science.1136188, 2007.

Loose, B. and Schlosser, P.: Sea ice and its effect on $\mathrm{CO}_{2}$ flux between the atmosphere and the Southern Ocean interior, J. Geophys. Res., 116, C11019, doi:10.1029/2010JC006509, 2011.

Loose, B., McGillis, W. R., Schlosser, P., Perovich, D., and Takahashi, T.: Effects of freezing, growth, and ice cover on gas transport processes in laboratory seawater experiments, Geophys. Res. Lett., 36, L05603, doi:10.1029/2008GL036318, 2009. 
Luz, B. and Barkan, E.: Assessment of oceanic productivity with the triple-isotope composition of dissolved oxygen, Science, 288, 2028-2031, doi:10.1126/science.288.5473.2028, 2000.

Luz, B. and Barkan, E.: The isotopic ratios ${ }^{17} \mathrm{O} /{ }^{16} \mathrm{O}$ and ${ }^{18} \mathrm{O} /{ }^{16} \mathrm{O}$ in molecular oxygen and their significance in biogeochemistry, Geochim. Cosmochim. Ac., 69, 1099-1110, doi:10.1016/j.gca.2004.09.001, 2005.

Luz, B. and Barkan, E.: Net and gross oxygen production from $\mathrm{O}_{2} / \mathrm{Ar},{ }^{17} \mathrm{O} /{ }^{16} \mathrm{O}$ and ${ }^{18} \mathrm{O} /{ }^{16} \mathrm{O}$ ratios, Aquat. Microb. Ecol., 56, 133-145, doi:10.3354/ame01296, 2009.

Luz, B. and Barkan, E.: Variations of ${ }^{17} \mathrm{O} /{ }^{16} \mathrm{O}$ and ${ }^{18} \mathrm{O} /{ }^{16} \mathrm{O}$ in meteoric waters, Geochim. Cosmochim. Ac., 74, 6276-6286, doi:10.1016/j.gca.2010.08.016, 2010.

Marra, J.: Approaches to the measurement of plankton production, in: Phytoplankton Productivity: carbon assimilation in marine and freshwater ecosystems, edited by: Williams, P. J. B., Thomas, D. N., and Reynolds, C. S., Blackwell Sci., Oxford, UK, 78-108, 2002.

Martin, J. H., Gordon, R. M., and Fitzwater, S. E.: The case for iron, Limnol. Oceanogr., 36, 1793-1802, doi:10.4319/lo.1991.36.8.1793, 1991.

Matear, R. J., Hirst, A. C., and McNeil, B. I.: Changes in dissolved oxygen in the Southern Ocean with climate change, Geochem. Geophy. Geosy., 1, 2000GC000086, doi:10.1029/2000GC000086, 2000.

Meredith, M. P. and King, J. C.: Rapid climate change in the ocean west of the Antarctic Peninsula during the second half of the 20th century, Geophys. Res. Lett., 32, L19604, doi:10.1029/2005GL024042, 2005.

Meredith, M. P., Wallace, M. I., Stammerjohn, S., Renfrew, I. A., Clarke, A., Venables, H. J., Shoosmith, D. R., Souster, T., and Leng, M.: Changes in the freshwater composition of the upper ocean west of the Antarctic Peninsula during the first decade of the 21st century, Prog. Oceanogr., 87, 127-143, doi:10.1016/j.pocean.2010.09.019, 2010.

Montes-Hugo, M., Sweeney, C., Doney, S. C., Ducklow, H. W., Frouin, R., Martinson, D. G., Stammerjohn, S., and Schofield, O.: Seasonal forcing of summer dissolved inorganic carbon and chlorophyll $a$ on the western shelf of the Antarctic Peninsula, J. Geophys. Res., 115, C03024, doi:10.1029/2009JC005267, 2010.

Mura, M. P., Satta, M. P., and Agustí, S.: Water-mass influences on summer Antarctic phytoplankton biomass and community structure, Polar Biol., 15, 15-20, doi:10.1007/BF00236119, 1995.

Nicholson, D. P., Stanley, H. R. R., Barkan, E., Karl, D. M., Luz, B., Quay, P. D., and Doney, S. C.: Evaluating triple oxygen isotope estimates of gross primary production at the Hawaii Ocean Timeseries and Bermuda Atlantic Time-series Study sites, J. Geophys. Res., 117, C05012, doi:10.1029/2010JC006856, 2012.

Perissinotto, R., Duncombe Rae, C. M., Boden, B. P., and Allanson, B. R.: Vertical stability as a controlling factor of the marine phytoplankton production at the Prince Edward Archipielago (Southern Ocean), Mar. Ecol-Prog. Ser., 60, 205-209, doi:10.3354/meps060205, 1990.

Pollard, R. T., Read, J. F., Allen, J. T., Griffiths, G., and Morrison, A. I.: On the physical structure of a front in the Bellingshausen Sea Deep-Sea Res. II, 42, 955-982, doi:10.1016/09670645(95)00064-W, 1995.

Reuer, M. K., Barnett, B. A., Bender, M. L., Falkowski, P. G., and Hendricks, M. B.: New estimates of Southern Ocean bi- ological production rates from $\mathrm{O}_{2} / \mathrm{Ar}$ ratios and the triple isotope composition of $\mathrm{O}_{2}$, Deep-Sea Res., 54, 951-974, doi:10.1016/j.dsr.2007.02.007, 2007.

Robinson, C., Tilstone, G. H., Rees, A. P., Smyth, T. J., Fishwick, J. R., Tarran, G. A., Luz, B., Barkan, E., and David, E.: Comparison of in vitro and in situ plankton production determinations, Aquat. Microb. Ecol., 54, 13-34, doi:10.3354/ame01250, 2009.

Sea-Bird Electronics, I.: Application Note no. 64-3, Sea Bird Electronics 43 Dissolved oxygen (DO) sensor - hysteresis correction, Application Note no. 64-3, Sea-Bird Electronics, Inc., Sea-Bird Electronics, I., Bellevue, WA, 1-7, 2010.

Serebrennikova, Y. M. and Fanning, K. A.: Nutrients in the Southern Ocean GLOBEC region: variations, water circulation, and cycling, Deep-Sea Res. II, 51, 1981-2002, doi:10.1016/j.dsr2.2004.07.023, 2004.

Smith, W. O. and Comiso, J. C.: Influence of sea ice on primary production in the Southern Ocean: A satellite perspective, J. Geophys. Res., 113, C05S93, 1-19, doi:10.1029/2007JC004251, 2008.

Smith, D. A., Hofmann, E. E., Klinck, J. M., and Lascara, C. M.: Hydrography and circulation of the West Antarctic Peninsula Continental Shelf, Deep-Sea Res. I, 46, 925-949, doi:10.1016/S0967-0637(98)00103-4, 1999.

Smith, R. C., Baker, K. S., and Vernet, M.: Seasonal and interannual variability of phytoplankton biomass west of the Antarctic Peninsula, J. Marine Syst., 17, 229-243, doi:10.1016/S09247963(98)00040-2, 1998.

Smith, W. O., Marra, J., Hiscock, M. R., and Barber, R.: The seasonal cycle of phytoplankton biomass and primary productivity in the Ross Sea, Antarctica, Deep-Sea Res. II, 47, 3119-3140, doi:10.1016/S0967-0645(00)00061-8, 2000.

Smith, R. C., Martinson, D. G., Stammerjohn, S., Iannuzzi, R. A., and Ireson, K.: Bellingshausen and western Antarctic Peninsula region: Pigment biomass and sea-ice spatial/temporal distributions and interannual variability, Deep-Sea Res. II, 55, 19491963, doi:10.1016/j.dsr2.2008.04.027, 2008.

Spitzer, W. S. and Jenkins, W. J.: Rates of vertical mixing, gas exchange and new production: Estimates from seasonal gas cycles in the upper ocean near Bermuda, J. Mar. Res., 47, 169-196, doi:10.1357/002224089785076370, 1989.

Sturm, M. and Masson, R. A.: 5. Snow and Sea Ice, in: Sea Ice, 2nd. ed., edited by: Thomas, D. N. and Dieckmann, G. S., John Wiley \& Sons Ltd., West Sussex, 621, 2010.

Sweeney, C., Gloor, E., Jacobson, A. R., Key, R. M., McKinley, G., Sarmiento, J. L., and Wanninkhof, R.: Constraining global air-sea gas exchange for $\mathrm{CO}_{2}$ with recent bomb ${ }^{14} \mathrm{C}$ measurements, Global Biogeochem. Cy., 21, GB2015, 1-10, doi:10.1029/2006GB002784, 2007.

Tortell, P. D.: Dissolved gas measurements in oceanic waters made by membrane inlet mass spectrometry, Limnol. Oceanogr.Meth., 3, 24-37, doi:10.4319/lom.2005.3.24, 2005.

Tortell, P. D. and Long, M. C.: Spatial and temporal variability of biogenic gases during the Southern Ocean spring bloom, Geophys. Res. Lett., 36, L01603, doi:10.1029/2008GL035819, 2009.

Tortell, P. D., Guéguen, C., Long, M., Payne, C. D., Lee, P., and DiTullio, G. R.: Spatial variability and temporal dynamics of surface sater $\mathrm{pCO}_{2}, \Delta \mathrm{O}_{2} / \mathrm{Ar}$ and dimethylsulfide in the Ross Sea, Antarctica, Deep-Sea Res., 58, 241-259, doi:10.1016/j.dsr.2010.12.006, 2011. 
Tortell, P. D., Long, M., Payne, C. D., Alderkamp, A.-C., Dutrieux, P., and Arrigo, K. R.: Spatial distribution of $\mathrm{pCO}_{2}, \Delta \mathrm{O}_{2} / \mathrm{Ar}$ and dimethylsulfide (DMS) in polynya waters and the sea ice zone of the Amundsen Sea, Antarctica, Deep-Sea Res. II, 71-76, 77-93, doi:10.1016/j.dsr2.2012.03.010, 2012.

Turner, D. R. and Owens, N. J. P.: A biogeochemical study in the Bellingshausen Sea: overview of the STERNA 1992 expedition, Deep-Sea Res. II, 42, 907-932, doi:10.1016/09670645(95)00056-V, 1995.

Vernet, M., Martinson, D., Iannuzzi, R., Stammerjohn, S., Kozlowiski, W., Sines, K., Smith, R., and Garibotti, I.: Primary production within the sea-ice zone west of the Antarctic Peninsula: I-Sea ice, summer mixed layer, and irradiance, Deep-Sea Res. II, 55, 2068-2085, doi:10.1016/j.dsr2.2008.05.021, 2008.
Wallace, M. I., Meredith, M. P., Brandon, M. A., Sherwin, T. J., Dale, A., and Clarke, A.: On the characteristics of internal tides and coastal upwelling behaviour in Marguerite Bay, west Antarctic Peninsula, Deep-Sea Res. II, 55, 2023-2040, doi:10.1016/j.dsr2.2008.04.033, 2008. 